\title{
Refugee Women and the Imperative of Categories
}

INTRODUCTION .......................... 214

I. WHO IS A REFUGEE? ................... 217

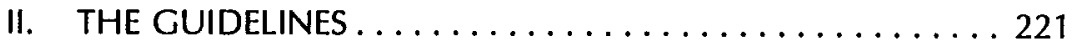

A. Persecution / Lack of Protection . . . . . . . . . . 222

1. Gendered Harms ..................... 222

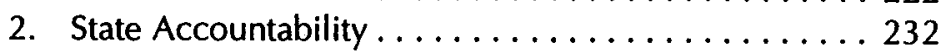

3. Prevalence of Gender Persecution . . . . . . . . . 236

B. Grounds of Persecution ................ 238

1. Race....................... 239

2. Religion ...................... 239

3. Nationality.................... 240

4. Political Opinion .................. 240

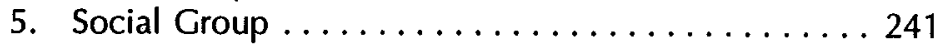

C. Procedural Issues . . . . . . . . . . . . . . . . . 248

D. Flaws and Gaps in the Guidelines ............ 249

III. REPRESENTING GENDER PERSECUTION .......... 252

A. Cultural Relativism and Gender Persecution ....... 252

B. Reinterpretation Versus Accretion............ 256

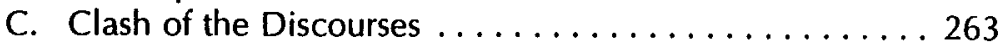

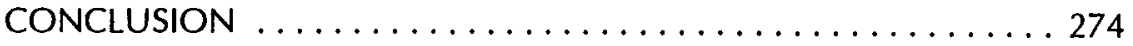

* Assistant Professor, Dalhousie Law School, Halifax Canada; Member, Canadian Immigration and Refugee Board. This article was written prior to the author assuming her position as a Member. The views expressed in this article are those of the author and do not necessarily reflect the views of the Immigration and Refugee Board. The author wishes to thank Vaughan Black, Richard Devlin, Elaine Gibson, Dianne Pothier, and Teresa Soassa for their helpful comments on earlier drafts. 


\section{INTRODUCTION}

The de facto uniting criterion [among refugees] was the shared marginalization of the groups in their states of origin, with consequent inability to vindicate their basic human rights at home. These early refugees were not merely suffering persons, but were moreover persons whose position was fundamentally at odds with the power structure in their home state. It was the lack of a meaningful stake in the governance of their own society which distinguished them from others, and which gave legitimacy to their desire to seek protection abroad.'

-James Hathaway

"Our country," she will say, "throughout the greater part of its history has treated me as a slave; it has denied me education or any share in its possessions. 'Our' country still ceases to be mine if I marry a foreigner. 'Our' country denies me the means of protecting myself ...." "For," the outsider will say, "in fact, as a woman, I have no country."

-Virginia Woolf, Three Guineas

On March 9, 1993, Canada's Immigration and Refugee Board (IRB) issued guidelines entitled "Women Refugee Claimants Fearing GenderRelated Persecution" ${ }^{3}$ (hereinafter Guidelines). The purpose of the Guidelines is to provide IRB decisionmakers with a means of interpreting the legal definition of a refugee in a gender sensitive manner. The Guidelines were issued amid public outcry over several well publicized incidents regarding the plight of women who had made unsuccessful refugee claims based on gender related persecution. In the first case, a Saudi woman, known as "Nada," defied the law of her country by refusing to wear a veil. For this transgression, she was spat upon, publicly harassed, and threatened with arrest by unofficial "religious police." The Convention Refugee Determination Division (CRDD) ${ }^{4}$ panel hearing her case castigated Nada for her effrontery:

Il lui faudrait bien, comme toutes ses compatriotes se conformer aux lois d'application générale qu'elle dénonce, et ce en toutes circonstances et non seulement, comme elle l'a fait pour étudier, travailler ou ménager les sentiments de son père qui, comme toute sa nombreuse famille, était opposé au liberalisme de sa fille la demanderesse. ${ }^{5}$

1. James C. Hathaway, The Law of Refugee Status 135-36 (1991).

2. VirGinia Woolf, Three Guineas 108-09 (1966).

3. Immicration and Refucee Board, Guidelines Issued by the Chatrperson Pursuant to Section 65(3) OF THE IMmiCRATION ACT, (1993) [hereinafter Guidelines]. The IRB adjudicates refugee claims made within Canadian borders, including those claims made at Canadian ports of entry.

4. The CRDD is the branch of the IRB that adjudicates refugee claims made inland or at port-of-entry.

5. "Like all Saudi Arabian women, the claimant would have to obey the laws of general application that she denounces, in all circumstances and not only, as she did, to attend 
Other cases involved women who fled their country of origin to escape husbands who physically or sexually abused them with impunity in countries where the criminal justice system offered no protection. The countries of origin included Trinidad, Bangladesh, Syria, Bulgaria, and Dominica. ${ }^{6}$ One case concerned a Trinidadian woman named Dularie Boodlal, whose husband abused her for seventeen years by beating her, cutting her with razors and knives, and slamming her head into a car door. She fled Trinidad for Toronto in 1988, only to be followed by her husband. After being convicted eleven times in Canada of either assaulting or uttering death threats at her, he voluntarily returned to Trinidad rather than serve a jail sentence in Canada. Dularie's husband continued to menace her via letters and phone calls, threatening to "chop her to pieces" ${ }^{\prime \prime}$ if she returned to Trinidad. A spokesman for Canadian Immigration justified the denial of refugee status, and the decision to deport Dularie, because Trinidad had recently passed a family violence statute so that "she can avail herself of the protection of the authorities in her own country." ${ }^{8}$

Without doubt, the Guidelines would not exist but for the concerted efforts of a coalition of feminist, human rights, refugee, and immigration activists, as well as the personal commitment and leadership of a committee of members working under the Chairperson of the IRB, Nurjehan Mawani. The content of the Guidelines reveal an indebtedness to thoughtful feminist analyses by Canadian and European authors about why and how to factor gender into refugee determinations. ${ }^{9}$ Another source of inspiration included

school, work or accommodate the feelings of her father who, like the other members of his large family, was opposed to the liberalism of his daughter, the claimant." No. M9104822, [1991] D.S.S.R. 1096 (Decisions de la Section du statut de refugie).

6. See Abuse-Refugee, 1st Ld, CANAdIAN Press, 10 Jan. 1993, available in QUICKLAW, CP93 Database; Refugee-Woman, Bgt, Canadian Press, 10 Feb. 1993, available in QUICKLAW, CP93 Database; Syrian-Woman-Immigration, CAnadian Press, 11 Feb. 1993, available in QUICKLAW, CP93 Database, Doc. No. 1811803; Women-Deported, Bgt, Canadian PrEss, 25 Feb. 1993, available in QUICKLAW, CP93 Database; Woman-Refugee, Canadian Press, 12 Nov. 1992, available in QUICKLAW, CP92 Database; WomenRefugee, Cxn Complete, Canadian Press, 2 Feb. 1993, available in QUICKLAW, CP93 Database.

7. Battered-Refugee, Canadian Press, 16 Sept. 1992, available in QUICKLAW, CP92 Database.

8. Id. The denial of refugee status for battered women typically turns on the absence of state responsibility for the alleged acts, and/or the inability to link the persecution to one of the enumerated grounds.

9. Articles cited in the GUIDELINES include: Jacqueline Greatbatch, The Gender Difference: Feminist Critiques of Refugee Discourse, 1 INT'L J. REFUGE L. 518 (1989); Felicite Stairs \& Lori Pope, No Place Like Home: Assaulted Migrant Women's Claims to Refugee Status, 6 J.L. \& Soc. Po''y 148 (1990); A.B. Johnsson, The International Protection of Women Refugees-A Summary of Principal Problems and Issues, 1 INT't J. RefugeE L. 221 (1989); L. Bonnerjea, Shaming the Worid: The Needs of Women Refucees (1985); C.E.J. de Neef \& S.J. de Ruiter, Sexual Violence Against Refugee Women (The Hague, Ministry for Social Affairs, 1984). See Guidelines, supra note 3 , at $11,14-15$. 
a few favorable decisions in past refugee claims. In addition, an international framework within which the Guidelines could emerge had already begun to crystallize in the late 1980s through the assiduous efforts of the United Nations High Commission for Refugees (UNHCR) Executive Committee. The most prominent among these projects was the publication of Guidelines on the Protection of Refugee Women ${ }^{10}$ (hereinafter UNHCR Gender Guidelines).

Shortly after the Canadian Guidelines were issued by the IRB, the Supreme Court of Canada released its long awaited decision in Canada (Attorney General) v. Ward." Key aspects of this judgment reinforce the Guidelines and provide an important (if indirect) judicial affirmation of the Guidelines' underlying principles. Though the Canadian Guidelines are not the first formal gesture made by an individual state toward recognizing gender persecution, ${ }^{12}$ they are by far the most comprehensive. Indeed, the spirit of the Guidelines (if not each letter) was welcomed by most Canadian commentators and applauded enthusiastically by US and British refugee activists. The Guidelines have been cited approvingly by US scholars hoping to nudge their government in a similar direction. ${ }^{13}$

On a more general plane, the Guidelines embody a pragmatic attempt to grapple with the complexities of invoking gender as a category. The stability of categories, and of gender in particular, has of late been the subject of lively debate among post-modern feminists. The alternate practices of deconstructing gender in the theoretical domain, while using it strategically in the real world, has generated an unresolved tension between theory and practice. Rather than engage this dilemma in its abstract formulation, I propose to use the Guidelines as an opportunity to inquire into the theoretical and practical implications of using gender as a category within the existing legal framework of refugee determination.

10. United Nations Hich Commissioner for Refugees, Guidelines on the Protection of Refucee WOMEn, U.N. Doc. ES/SCP/67 (1991) [hereinafter UNHCR Gender Guidelines].

11. [1993] 2 SCR 689.

12. The Dutch Refugee Council issued the following policy directive in 1984:

It is the opinion of the Dutch Refugee Council that persecution for reasons of membership of a particular social group, may also be taken to include persecution because of social position on the basis of sex. This may be especially true in situations where discrimination against women in society, contrary to the rulings of international law, has been institutionalized and where women who oppose this discrimination, or distance themselves from it, are faced with drastic sanctions, either from the authorities themselves, or from their social environment, where the authorities are unwilling or unable to offer protection.

Guidelines, supra note 3 , at 13 n.6. The European Parliament also passed a similar resolution in 1984. See id. at 12, n.6.

13. See Pamela Goldberg, Anyplace but Home: Asylum in the United States for Women Fleeing Intimate Violence, 26 CORNeu INT'L L.J. 565, 584 (1993); Nancy Kelly, GenderRelated Persecution: Assessing the Asylum Claims of Women, 26 CORNELL INT'L L.J. 625, 633 (1993). 
Part I examines the operational scope of the Guidelines in the broader context of Canadian and international refugee law, and refutes the "floodgates" argument that asserts that hordes of desperate women will surge toward Canadian shores. However, Part I also qualifies the claims of those who might overstate the practical benefits of the Guidelines for the millions of displaced women in the world today.

Part II explains the substantive and procedural content of the Guidelines, using fact patterns derived from women's claims in Canada and elsewhere to illustrate how the Guidelines would operate. Part II also addresses some of the gaps and omissions in the Guidelines.

Part III responds to the main critiques levelled against the Guidelines. First, it replies to the riposte of cultural imperialism advanced by those who resist the recognition of gender persecution in refugee law. Next, Part III addresses the contention that anything short of adding gender to the list of grounds of persecution in the refugee definition is an inferior and inadequate response. In so doing, Part III rejoins the question of categories in its concrete application, and queries the tactical merits of augmentation versus reinterpretation of existing categories.

Part III also focuses on the respective paradigms within which refugee and feminist discourses operate. By allowing space for the twin claims that gender oppression in the name of religion, tradition, or biology may indeed be persecution, and that women are persecuted because they are women, the Guidelines appear to integrate key feminist insights into the official corpus of refugee discourse. Without detracting in any way from the Guidelines' many virtues, this section attempts to expose this alliance as a locus of considerable tension and even paradox. Finally, the conclusion questions the extent to which the feminist vector guiding the recognition of gender persecution can be contained within the orbit of conventional refugee law.

\section{WHO IS A REFUGEE?}

The popular understanding of "refugee" typically encompasses people who have been uprooted and forced to flee their countries of nationality because of war, famine, natural disaster, or human rights abuses. Using this definition, approximately 80 percent of the world's twenty-some million refugees are women and children. ${ }^{14}$ In order to acquire the legal status of a

14. Susan Forbes Martin, Refugee Women 1 (1992); see also Monica Boyd, Gender Concealed, Gender Revealed: The Demography of Canada's Refugee Flows, in Gender Issues And Refugees: Development Implications, Conference Proceeongs 173 (York University, 9-11 May 1993). 
refugee in Canada, however, a claimant must prove that she comes within the refugee definition contained in the UN Convention relating to the Status of Refugees. ${ }^{15}$ This definition is applied by all states parties to the Convention, and has been incorporated into Section 2 of Canada's Immigration Act:

"Convention refugee" means any person who,

(a) by reason of a well-founded fear of persecution for reasons of race, religion, nationality, membership in a particular social group or political opinion,

(i) is outside the country of the person's nationality and is unable or, by reason of that fear, is unwilling to avail [her]self of the protection of that country, or

(ii) not having a country of nationality, is outside the country of the person's former habitual residence and is unable or, by reason of that fear, is unwilling to return to that country,

(b) has not ceased to be a Convention refugee .... ${ }^{16}$

In brief, a claimant must demonstrate that she fled because of a legitimate fear of persecution occasioned by her "race, religion, nationality, membership in a particular social group or political opinion." This legal definition automatically eliminates millions of women from the Convention refugee roster, not because the impetus for their flight was gender-specific, but because starvation, war, and environmental disaster "don't count" for purposes of the legal definition. Regional instruments in Africa" and the Americas $^{18}$ have supplemented the Convention refugee definition with provisions that encompass victims of inter alia, civil war, events seriously disturbing public order, or situations of massive human rights violations. Unfortunately, Canada is party to neither instrument. Canadian law implements the narrow refugee definition contained in the Convention. This relatively narrow formulation reflects the Eurocentric liberal rights paradigm from which it emerged. As such, it focuses on the violation of liberal

15. Opened for signature July $28,1951,189$ U.N.T.S. 137. The geographic and temporal range of the Convention was expanded by the Protocol relating to the Status of Refugees, opened for signature 31 Jan. 1967, 606 U.N.T.S. 8791. Hereinafter, the Convention refers to the cumulation of the two instruments.

16. R.S.C. 1985, c.I-2, §2(1).

17. Organization of African Unity, Convention governing the specific aspects of refugee problems in Africa, entered into force 20 June 1974, 1001 U.N.T.S. 46 (supplementing the Convention definition by recognizing claims based on "external aggression, occupation, foreign domination or events seriously disturbing public order in either part of the whole of his country of origin or nationality .....").

18. Organization of American States, Declaracion de Cartagena, Doc. OEA/Ser.L./II.66, Conclusion 3 (status recommended for persons fleeing "Generalized violence, foreign aggression, internal conflicts, massive violations of human rights or other circumstances which have seriously disturbed public order"). 
individual rights for which the state may be held accountable. Its conceptual framework must also be assessed against the Cold War climate in which it was drafted. ${ }^{19}$ In any event, the confined scope of the Convention refugee definition necessarily has a disproportionately severe impact on women and children, because they comprise the bulk of the world's displaced people. Nothing in the new Guidelines ameliorates this harsh reality.

Convention refugees are admitted to Canada via two routes: selection abroad and inland, or port-of-entry, claims. ${ }^{20}$ About two-thirds of Canada's annual intake are chosen and sponsored from abroad by the Canadian government, and roughly 60 percent of adults selected overseas since 1991 have been men. ${ }^{21}$ The Guidelines do not govern overseas selection and will not affect this process, even though overseas selection generates a pool of refugees where men are clearly over-represented. ${ }^{22}$ Androcentric application of the refugee definition may partly account for the disproportionate numbers of male refugees selected abroad, but Canada compounds the anomaly with the addition of a "personal suitability" or "admissibility" component above and beyond the refugee selection criteria. As Monica Boyd explains,

For admission into Canada from outside the country, a person first must meet the United Nations criteria of a convention refugee .... But the person then also must meet the criteria of admissibility, which generally means that the person should exhibit the potential for eventual successful settlement in Canada. The characteristics used to evaluate such potential are largely of a socio-economic nature, such as exposure to Western lifestyles, education, job skills, and knowledge of English or French. These criteria do not include gender. However, these gender-free criteria are not gender neutral in their consequences. Gender stratification in many countries means that women receive fewer educational opportunities than men, are less likely to acquire English or French language skills as part of schooling, and may have less exposure to urban or industrial jobs. Furthermore, given the gender gap in Canadian wages, women may be considered less economically self-sufficient than men if they have many dependents. Finally, gender stratification in refugee camps also can result in male refugees occupying important mediating positions that increase the chances of selection for resettlement. ${ }^{23}$

19. For a brief overview of the drafting history of the Convention, see HathaWay, supra note 1 , at 6-10.

20. Canada also admits a variety of individuals in "refugee like" situations on an ad hoc basis. In the past, these have included Vietnamese boat people, self-exiles, and internally displaced. These individuals are admitted under the rubric of "designated group." See Boyd, supra note 14.

21. Canadian Council for Refugees, Consultation on Gender Issues and Refugees, at 23 (Fall 1993).

22. Overseas selection is performed by staff within the Department of Citizenship \& Immigration, and falls outside the jurisdiction of the Immigration and Refugee Board.

23. Boyd, supra note 14, at 12-13; see also Doreen Indra, Gender: A Key Dimension of the Refugee Experience, 6 Refuge 3, 3-4 (1987). 
In the mid-1980s, the UNHCR acknowledged the gender skew in overseas selection and launched an initiative known as the Women at Risk (AWR) programme. The programme targets women in refugee camps who are in immediate peril of harassment, physical/sexual abuse or refoulement. Candidates may also be drawn from the pool of those "existing in permanently unstable circumstances which allow for no other remedy." ${ }^{24}$ These include women who qualify as Convention refugees, but present poor resettlement prospects because they 1) have many small children and no spouse, 2) have low skill levels, or 3) for other reasons "have been passed over by Canada or by other resettlement countries in the past. ${ }^{25}$ Participating states acknowledged that the costs associated with successful resettlement may be higher for Women at Risk than other refugees.

Canada was the first to respond to the UNHCR initiative in 1988. ${ }^{26}$ Between 1988 and July 1993, Canada accepted a total of 586 women and children through the AWR Programme. ${ }^{27}$ As of 1991, Women at Risk comprised 0.8 percent of the 48,723 Convention refugees accepted into Canada. ${ }^{28}$ In other words, the AWR Programme, laudable in its conception, has in practice scarcely touched the numbers and proportion of women refugees resettled in Canada.

Because the Guidelines only apply to the determination of refugee claims within Canada, they do not apply to women unable to make the journey to Canada. Approximately two-thirds of asylum seekers in Canada are male. ${ }^{29} \mathrm{~A}$ variety of psychological, cultural, and financial impediments render women less able than men to undertake the hazardous, uncertain, and expensive journey to Canada. The new Guidelines will not eliminate the array of obstacles blocking women's access to the refugee determination process. As Nada herself explained,

First of all, it's very hard to leave [Saudi Arabia]. Even if a woman thinks about leaving, she cannot get permission. It's also not easy for a woman to do things by herself. Women are raised to be incapable of doing anything. One pays a big price to come here and the woman who is willing to do that is rare. ${ }^{30}$

Refugee scholar James Hathaway confirmed the bleak options available to women who flee when he stated, "We're not going to see a flood of

24. Citizenship and Immigration, Immigration Manual (Selection and Control) IS 3.13, No. 2, June 1990.

25. Id.

26. New Zealand and Australia have since developed similar programs

27. Consultation on Gender Issues and Refugees, supra note 21, at 26.

28. Boyd, supra note 14, at 187.

29. Id. at 178. Curiously, women claimants were slightly more successful in their claims than their male cohorts. Id. at 183.

30. Ed Broadbent, Director of the International Centre for Human Rights and Democratic Development made the same point even more trenchantly: "The women we're talking 
female claimants. Most women can't get out of their countries, and when they can, they're lucky to make it to the next country. ${ }^{\prime \prime 1}$ The reality is that permanent resettlement or asylum in a remote country like Canada will never be a viable or even desirable option for the overwhelming majority of displaced women, quite apart from whether gender persecution is recognized as a basis for refugee status. Scaremongers who invoke the spectre of "tens of millions of [women] refugees" ${ }^{32}$ swarming the Canadian border should feel chastened by this fact; advocates who hail the Guidelines as a major breakthrough in refugee protection should likewise feel tempered in their enthusiasm.

\section{THE GUIDELINES}

Notably, the Guidelines do not alter the statutory definition of a refugee. That is to say, they do not add gender to the grounds of persecution, grounds that currently consist of "race, religion, nationality, membership in a particular social group or political opinion." Indeed, the IRB lacks jurisdiction to amend the refugee definition; only Parliament can do so. Instead, the Guidelines offer members of the CRDD a way of interpreting the existing Convention refugee definition in a manner that recognizes the interplay between gender and persecution. The Guidelines proceed from the following general proposition:

Although gender is not specifically enumerated as one of the grounds for establishing Convention refugee status, the definition of Convention refugee may properly be interpreted as providing protection to women who demonstrate a well-founded fear of gender-related persecution by reason of any, or a combination of, the enumerated grounds. ${ }^{33}$

In essence, the Guidelines supply advice on gender-sensitive approaches to statutory interpretation. They cannot bind individual decisionmakers, as this would fetter their discretion. ${ }^{34}$ While the Guidelines are not

about can't jump in the car and go to the airport to buy a ticket; they aren't permitted to drive. And they don't exactly have an American Express gold card that they could use to buy tickets to fly here." Women-Refugees, Bgt, CAN. Press, 10 Jan. 1993, available in QUICKLAW, CP93 Database.

31. Domestic Abuse Accepted for Refugee Status, Globe And Mal, 10 Feb. 1993, at A1, A2.

32. Women-Refugees, Bgt, supra note 30 (remarks of Bernard Valcourt, then Minister of Employment \& Immigration); see also Barbara Amiel, The female refugee: a fraudulent concept, MACLEAN's MAG., 29 Mar. 1993, at 9.

33. Guidelines, supra note 3 , at 2 .

34. The administrative law principle of fettering discretion requires that in applying a law (in this instance the $(m m i g r a t i o n ~ A c t)$, a decisionmaker cannot be restricted in her task by something less than law (in this instance the Guidelines). The Guidelines can only guide, they cannot compel. 
law, the Chair of the IRB gives members a bureaucratic incentive to take them seriously. Members must provide written reasons for any decision that rejects the principles adumbrated in the Guidelines.

The Guidelines address both substantive and procedural aspects of gender as they pertain to refugee determination. I begin with the former and employ key components of the refugee definition as a framework for analysis. In order to establish entitlement to refugee status, the claimant must prove that:

A. She has a well-founded fear of mistreatment that qualifies as persecution;

B. The reason for her fear relates to one or more of the listed grounds (race, religion, nationality, membership in a particular social group or political opinion).

\section{A. Persecution / Lack of Protection}

Persecution contains two elements. The first is whether the harm apprehended by the claimant amounts to persecution. ${ }^{35}$ The second is whether the state can be held accountable, in some measure, for the infliction of the harm. One may be a victim of a violent crime, but that does not necessarily make one the victim of persecution. The Guidelines illuminate various ways in which gender is implicated in both the recognition of harm and the attribution of state responsibility.

\section{Gendered Harms}

Persecution is not defined in the Convention, and its meaning is deliberately left vague in the UNHCR Handbook on Procedures and Criteria for Determining Refugee Status ${ }^{36}$ (hereinafter UNHCR Handbook). The UNHCR Handbook indicates that:

a threat to life or freedom on account of race, religion, nationality, political opinion or membership of a particular social group is always persecution. Other

35. See Hathaway, supra note 1 , at 99.

36. Office of the United Nations High Commissioner for Refugees, Handbook on Procedures and Criteria for Determining Refugee Status (Geneva, Sept. 1979, re-edited Jan. 1992) [hereinafter "UNCHR Handbook"]. The Handbook is meant as a guide to interpretation; it exerts no binding authority over States Party to the Convention. As such, it occupies the same status vis à vis States Party as the Guidelines do vis à vis the Members of the CRDD. 
serious violations of human rights-for the same reasons-would also constitute persecution. ${ }^{37}$

Elsewhere, the UNHCR Handbook adds that other "prejudicial actions or threats" may amount to persecution depending on the particular circumstances. In addition, individual acts that might not amount to persecution when examined in isolation, may assume the character of persecution when viewed in their totality. ${ }^{38}$

Canadian jurisprudence has wrestled with the task of concretely defining persecution. Various decisions have confirmed that persecution encompasses more than threats to physical security and freedom. As stated in Luis Enrique Toha Sequel, "we are not talking about physical torture alone, but about any act intended to deny or trample on a person's fundamental rights." ${ }^{39}$ The Supreme Court of Canada recently cited with approval a definition of persecution as "sustained or systemic violation of basic human rights demonstrative of a failure of state protection." 40 The linkage between persecution and the abrogation of basic human rights compels an articulation of what authoritatively constitutes a "human right."

The Guidelines deal with this thorny question by advising decisionmakers to consult international human rights instruments for assistance: ${ }^{41}$

(a) For the treatment to likely amount to persecution, it must be a serious form of harm which detracts from women's human rights and fundamental freedoms.

(b) In passing judgment on what kinds of treatment are considered persecution, an objective standard is provided by international human rights instruments that declare the lowest common denominator of protected interests. ${ }^{42}$

The Guidelines excerpt ${ }^{43}$ relevant provisions from various international instruments, including the International Covenant on Civil and Political Rights (ICCPR) ${ }^{44}$ and the International Covenant on Economic, Social and Cultural Rights (ICESCR). ${ }^{45}$ These are cited as authority for the general propositions that women and men are equally entitled to the civil, political, economic, social, and cultural rights guaranteed under international law,

\footnotetext{
37. See id. at 9 51.

38. Id. at 952 .

39. HathaWay, supra note 1 , at 108.

40. Ward, supra note 11, per Justice La Forest (former member of Irish National Liberation Army fleeing retaliation from INLA may claim refugee status if, inter alia, Ireland cannot protect him.)

41. Guidetines, supra note 3 , at 7 .

42. Id. at 10 .

43. See id. at $18-20$.

44. G.A. Res. 2200 (XXI), U.N. GAOR, 19 Dec. 1966, entered into force 23 Mar. 1976, 999 U.N.T.S. 171.

45. G.A. Res. 2200 (XXI), 19 Dec. 1966, entered into force 3 Jan. 1976, 993 U.N.T.S. 3.
} 
including the right to life, liberty and security of the person; and the right to be free from torture, or other cruel, inhuman, or degrading treatment or punishment. ${ }^{46}$ The Guidelines also cite the Convention on the Political Rights of Women ${ }^{47}$ (women's franchise and the right to stand for election and hold public office), the Convention on the Nationality of Married $W{ }^{2}{ }^{48}$ (right to retain nationality regardless of her spouse's nationality), and the Convention on Consent to Marriage, Minimum Age for Marriage and Registration of Marriages ${ }^{49}$ (right not to enter into marriage without full and free consent, and the right not to be married until reaching a minimum age). Though not mentioned in the Guidelines, other international instruments, such as the United Nations Universal Declaration of Human Rights ${ }^{50}$ (UDHR) and the Convention Against Torture and Other Cruel, Inhuman or Degrading Treatment or Punishment, ${ }^{51}$ provide additional sources of international human rights norms.

Though international human rights instruments provide a reference point for assessing the seriousness of the harm inflicted on a claimant, it is important to note that in the international realm, all rights are not created equal. James Hathaway has catalogued the emergence of a hierarchy of rights contained in the "International Bill of Rights" (the UDHR, ICCPR, and the ICESCR)..$^{52}$ First order rights are non-derogable in any circumstances and include the right not to be arbitrarily deprived of life; freedom from torture and other cruel, inhuman, or degrading treatment or punishment; freedom from slavery; and freedom of thought, conscience, and religion. Denial of these rights will always constitute persecution. Second order rights include freedom from arbitrary arrest and detention; right to a fair trial; right to equal protection; presumption of innocence; freedom of opinion, expression, assembly, and association; and the franchise. States may derogate from these rights during an officially proclaimed public emergency. Otherwise, denial of these rights also constitutes persecution. Third order rights engage the positive duties of a state to progressively work toward the achievement of a right to work; favorable conditions of employment; entitlement to food,

46. ICCPR (Art. 3: "The States Parties to the present Covenant undertake to ensure the equal right of men and women to the enjoyment of all civil and political rights set forth in the present Covenant."); ICESCR (Art. 3: "The States Parties to the present Covenant undertake to ensure the equal right of men and women to the enjoyment of all economic, social and cultural rights set forth in the present Covenant.").

47. 193 U.N.T.S. 135, 31 Mar. 1953, entered into force 7 July 1954.

48. 309 U.N.T.S. 65,20 Feb. 1957, entered into force 11 Aug. 1958.

49. 521 U.N.T.S. 231, 10 Dec. 1952, entered into force 9 Dec. 1964. The Guidelines acknowledge that Canada has not ratified this Convention.

50. Universal Declaration of Human Rights, signed 10 Dec. 1948, G.A. Res. 217A (III), U.N. Doc. A810, at 71 (1948).

51. Convention Against Torture and Other Cruel, Inhuman or Degrading Treatment or Punishment, G.A. Res. 39/46, 10 Dec. 1985, entered into force 26 June 1987.

52. Hathaway, supra note 1 , at 108-11. 
shelter, clothing, medical care, social security, and basic education; and protection of the family, especially children and mothers. These rights are unenforceable, but states are required to undertake a good faith effort, within the limits of available resources, to realize the goals in a nondiscriminatory way. Fourth order rights do not rise above the hortatory, and include the right to own and be protected from arbitrary deprivation of property, and protection against unemployment.

Feminist scholars in international law contend that the structure and content of international legal discourse is gendered at a number of levels, not least of which is its ordering of priorities. ${ }^{53}$ Having said that, it is not necessary to enter that debate here, because the fact remains that violations of women's "first" and "second order" rights are sufficiently routine and rampant ${ }^{54}$ that one can provisionally take the model on its own terms and still find massive derogation from the so-called higher order rights of women.

The Guidelines observe that women are punished, abused, violated, and terrorized for reasons that only apply to women, and in ways that can only be committed against women. Each example recounted in the Guidelines patently threatens "first order" international human rights to life, security of person, and bodily integrity:

The circumstances which give rise to women's fear of persecution are often unique to women. The existing bank of jurisprudence on the meaning of persecution is based on, for the most part, the experiences of male claimants. Aside from a few cases of rape, the definition has not been widely applied to female-specific experiences, such as infanticide, genital mutilation, brideburning, forced marriage, domestic violence, forced abortion, or compulsory sterilization. ${ }^{55}$

Rape should be one of the least controversial examples of persecution, though this has not always proven to be the case. The UNHCR Gender Guidelines graphically depict the use of sexual assault as an instrument to torture women:

Persecution of women often takes the form of sexual assault. The methods of torture can consist of rape, the use of electric currents upon the sexual organs; mechanical stimulation of erogenous zones; manual stimulation of the erog-

53. For critiques about the masculinist (and first world) orientation of international human rights discourse, see Hilary Charlesworth et al., Feminist Approaches to International Law, 85 AM. J. INT'L L. 613 (1991); Karen Engle, International Human Rights and Feminism: When Discourses Meet, $13 \mathrm{MICH}$. J. INT'L. L. 517 (1992); Hilary Charlesworth, What are 'Women's international Human Rights, in Human Rights of Women 58-84 (Rebecca Cook ed., 1994).

54. For a recent exploration of this topic, see Catharine Mackinnon, Rape, Genocide, and Women's Human Rights, 17 HARv. WOMEN's L. J. 5 (1994).

55. GUIDELINES, supra note 3 , at 7 . 
enous zones; the insertion of objects into the body-openings (with objects made of metal or other materials to which an electrical current is later connected); the forced witnessing of unnatural sexual relations; forced masturbation or to be masturbated by others; fellatio and oral coitus; and finally, a general atmosphere of sexual aggression and threats of the loss of the ability to reproduce and enjoyment of sexual relations in the future. ${ }^{56}$

Women may be sexually assaulted by state actors in a myriad of circumstances. Women detained for political reasons may be raped (along with other forms of torture) as part of interrogation. Women imprisoned or detained for non-political reasons may be raped for the amusement of their captors. Civilian women may be raped by government or opposition militia as part of a campaign to terrorize the local population, punish politically active males by proxy, or "reward" victorious combatants with the bodies of vanquished women. ${ }^{57}$

Some decisionmakers have proven unable to grasp the nature of rape by state actors as an integral and tactical part of the arsenal of weapons deployed to brutalize, dehumanize, and humiliate women and demoralize their kin and community. In Campos-Guardado v. Immigration and Naturalization Service, ${ }^{58}$ the United States Fifth Circuit Court of Appeals preferred to characterize such an act as the random expression of spontaneous sexual impulses by an individual military officer toward a woman, who happened to be captured while in the company of an uncle suspected of subversive political activities ${ }^{59}$-in other words, a common crime. In another US case, an Immigration Judge concluded that the rape of a Salvadoran claimant by a soldier who accused her of being a guerilla was not tacitly sanctioned activity, but "was more because she was a female convenient to a brutal soldier acting only in his own self-interest. ${ }^{\prime 60}$

56. UNHCR Gender Guidelines, supra note 10, at 179 (emphasis in original).

57. Various human rights agencies have documented these practices of sexual violence against women in numerous countries of the world. See AMnestY InTERNATIONAL, RAPE AND Sexual Abuse: Torture and lll Treatment of Women in Detention (Al/London, 1992); Amnesty International, India: Torture Rape and Deaths in Custody (Al/London, 1991); Amnesty International, Women in the Front Line: Human Rights Violations Against Women (Al/New York, 1991); Human Rights Watch, Double Jeopardv: Police Abuse of Women in Pakistan (Human Rights Watch/New York, 1992); Human Richts Watch, Criminal Injustice: Violence Against Women in Brazil (Human Rights Watch/New York, 1991). Human Rights Watch, Untold Terror: Violence Against Women in Peru's Armed Conflict (Human Rights Watch/ New York, 1992).

58. 809 F.2d 285 (5th Cir. 1987).

59. Id. at 289; see also Klawitter v. INS, 970 F.2d 149, 152 (6th Cir. 1992). For a discussion of the American jurisprudence in this area, see Kelly, supra note 13, at 638-42, and Jacqueline Castel, Rape, Sexual Assault and the Meaning of Persecution, 4 INT'L J Ref. L. 39 (1992).

60. Quoted in Amnesty International, Women in the Front Line, supra note 58, at 17. This construction of rape as a spontaneous "out of control" act by a renegade individual is central to rape mythology in non-war settings as well. It may be that judges unwittingly 
Other tribunals have refused to recognize widespread rapes by hostile militia as persecution, dismissing them as the common fate of women caught in a war zone. ${ }^{61}$ Why the indiscriminate (but systematic) nature of rape of civilian women by militia is relevant to the characterization of rape as persecution is unclear, but I suspect that the force of this argument has most likely diminished under the glare of mass rapes in the former Yugoslavia and the concomitant insistence that such violations are indeed war crimes. ${ }^{62}$ In addition, a German appellate court recently overturned the rejection of a Romanian claimant, who had been abducted and sexually and physically abused for two weeks by the town mayor and two policemen after refusing to have sex with the mayor in exchange for a work permit. The tribunal determined that the maltreatment constituted criminal acts by private actors; the court ruled that they were acts of persecution by state authorities. ${ }^{63}$

Canadian tribunals have explicitly found that threats of rape and rape itself "are degrading and constitute quite clearly an attack on the moral integrity of the person and, hence, persecution of the most vile sort." ${ }^{164}$ The Guidelines confirm that rape may qualify as a form of persecution. ${ }^{65} \mathrm{It}$ should be noted, however, that this recognition does not lead inexorably to the acceptance of a claimant as a refugee. For example, her credibility may still be challenged; the rape may yet be dismissed as a "common crime," especially if perpetrated by a private actor; or the decisionmaker may fail to see a nexus between the sexual abuse and a Convention ground. The Guidelines address these issues directly or by implication; ${ }^{66}$ these aspects of the Guidelines will be described infra.

Even before the Guidelines, various CRDD and Federal Court of Appeal decisions furnished examples of persecution experienced mainly (if not

resist seeing rape as part of an organized, deliberate campaign of terror against women during wartime because it would undermine their prevailing view about the practice of rape in peacetime.

61. For a description of this trend in Germany, see Margit Gottstein, Women Refugees and Asylum Policy in the Federal Republic of Germany: An Analysis of Aims and Results, in Gender Issues and Refugees, supra note 14, 531-33.

62. See, e.g., Theodor Meron, Rape as a Crime Under International Humanitarian Law, 87 AM J. INT'L L. 424 (1993). Human Rights Watch has documented the rape of Peruvian women by government security forces. According to a human rights organization in Peru, "Rape is a common part of the interrogation. They often do it just for fun." Peruvian Security Forces Accused of Indiscriminate Rape, Globe And Mall, 2 Feb. 1994, at A9.

63. Case abstract IJRL/0154, 5 INT'L J. ReF LAW 275 (1993) (Administrative Court of Bavaria, Ansbach, AN 17 K 91.44245, 1992).

64. Maria Veronica Rodriguez Salinas Araya, Immigration Appeal Board Decision 76-1127, 6 Jan. 1977, at 8, quoted in HathaWAY, supra note 1, at 112, n.109.

65. GUIDELINES, supra note 3 , at 7 .

66. [1993] 2 FC 314 (FCA). 
exclusively) by women. For example, in a case released the month preceding the Guidelines, a CRDD panel referred to the UDHR and the Convention on Consent to Marriage in arriving at the conclusion that forced marriage of a fifteen-year-old Zimbabwean girl to a polygamous man, followed by years of physical and sexual brutality, amounted to persecution. ${ }^{67}$ Compulsory sterilization of a woman who violated China's one child policy was also recognized as persecution by the Federal Court of Appeal in Cheung v. Canada (Minister of Employment and Immigration), ${ }^{68}$ although at least one other panel on the Federal Court of Appeal came to the opposite conclusion in the case of a male claimant. ${ }^{69}$

Gender persecution need not take the form of direct attacks on the physical integrity of women. According to the UNHCR Handbook, discrimination may amount to persecution if the measures "lead to consequences of a substantially prejudicial nature for the person concerned, e.g., serious restrictions on his [sic] right to earn his livelihood, his right to practise his religion, or his access to normally available educational facilities."70 Sexbased discrimination is practiced universally and is enforced through law, social custom, and individual practices; it also violates the rights guaranteed in the UN Convention on the Elimination of All Forms of Discrimination Against Women (CEDAW): ${ }^{71}$

Article 1: For the purposes of the present Convention, the term "discrimination against women" shall mean any distinction, exclusion or restriction made on the basis of sex which has the effect or purpose of impairing or nullifying the recognition, enjoyment or exercise by women, irrespective of their marital status, on a basis of equality of men and women, of human rights and fundamental freedoms in the political, economic, social, cultural, civil or any other field.

Article 2: States Parties condemn discrimination against women in all its forms and agree to pursue, by all appropriate means and without delay, a policy of eliminating discrimination against women and, to this end, undertake

(a) To embody the principle of the equality of men and women in their national Constitutions or other appropriate legislation if not already incorporated therein, and to ensure, through law and other appropriate, means, the practical realization of this principle; ... .

67. No. U92-06668, Smith, Daya, 19 Feb. 1993.

68. [1993] 2 FC 314 (FCA).

69. Chan v. Canada (Minister of Employment and Immigration (1993), $20 \mathrm{Imm} . \mathrm{LR}$ (2d) 181. Considering that the decision in Cheung was cited with approval on the persecution point by the Supreme Court of Canada in Ward, the ruling in Chan is surprising (Chan is currently on appeal to the Supreme Court of Canada).

70. UNHCR Handbook, supra note 36 , at if 54.

71. Convention on the Elimination of All Forms of Discrimination Against Women, adopted 18 Dec. 1979, entered into force 3 Sept. 1981, G.A. Res. 34/180, U.N. Doc. A/RES/34/ 180 (1980), 19 International Legal Materials 33 (1980). 
(e) To take all appropriate measures to eliminate discrimination against women by any person, organization or enterprise;

(f) To take all appropriate measures, including legislation, to modify or abolish existing laws, regulations, customs and practices which constitute discrimination against women;

(g) To repeal all national penal provisions which constitute discrimination against women.

In 1990, the UNHCR Executive Committee affirmed the linkage between a violation of the rights guaranteed under CEDAW and persecution for purposes of the Refugee Convention, stating that severe discrimination prohibited by CEDAW can form the basis for the granting of refugee status. ${ }^{72}$ At the same time, the UNHCR Gender Guidelines acknowledge that "the dividing line between discrimination and persecution is not a clear one."173 The Canadian Guidelines affirm that "severe discrimination on grounds of gender" can contribute to a finding of persecution, if "it leads to consequences of a substantially prejudicial nature for the claimant and if it is imposed on account of any one, or combination, of the statutory grounds for persecution.. ${ }^{174}$ Unfortunately, neither the UNHCR Gender Guidelines nor the Canadian Guidelines assist in distinguishing persecution from "mere" discrimination. ${ }^{75}$ Nevertheless, to the extent that discrimination may be sanctioned unofficially as "policy" or formally in law, the Guidelines provide the following clues:

A woman's claim to Convention refugee status cannot be based solely on the fact that she is subject to a national policy or law to which she objects. The claimant will need to establish that:

(a) the policy or law is inherently persecutory; or

(b) the policy or law is used as a means of persecution for one of the enumerated reasons; or

72. UNHCR Executive Committee, Note on Refugee Women and International Protection, $\mathrm{EC} / \mathrm{SCP} / 59$ (28 Aug. 1990), at 5.

73. UNHCR Gender Guidelines, supra note 10 , at If 36.

74. GuideINEs, supra note 3 , at 3 .

75. The Legal Services Division of the IRB recently attempted to distil the operative principles emerging from a series of discrimination-based claims into a usable framework for assessing whether discrimination amounts to persecution. The proposed test requires consideration of the type of right or freedom threatened by the discrimination, the basis of the threat, the nature and persistence of the discriminatory measures, and the seriousness of the harm to the claimant in the context of all the circumstances. Discrimination affecting so-called "first level rights" will more readily be characterized as persecution than infringement of lower order rights. The latter may also constitute 
(c) the policy or law, although having legitimate goals, is administered through persecutory means; or

(d) the penalty for non-compliance with the policy or law is disproportionately severe. $^{76}$

Although the Guidelines do not elaborate upon the foregoing propositions, the following examples may furnish plausible illustrations. In Nada's case, it may be argued that a policy ${ }^{77}$ compelling her to veil violates her "first order" freedom of religion or conscience. The premise is that if the law discriminates by selectively abrogating fundamental human rights of designated groups, the law itself persecutes. In principle, it should not matter that it would be relatively "easy" for the claimant to obey the law (and thus avoid prosecution) by wearing a veil, if in so doing she must forsake a protected freedom. ${ }^{78}$

An alternative-and perhaps preferable-approach might analyze the Saudi dress code by considering the plethora of rules, policies, customs, and laws circumscribing the lives of Saudi women. Women are not allowed to drive, must sit at the back of public buses, are limited in their educational and employment opportunities, and may not travel without the consent of a male relative. Assuming that women qualify as a "particular social group" under the Convention refugee definition, the restrictions on dress may be understood as one strand in a web of oppression that cumulatively amounts to persecution of Saudi women. The various restrictions lead to "consequences of a substantially prejudicial nature for the claimant ${ }^{\prime 79}$ in terms of

persecution, however, if the measures are persistent, systematic and "seriously affect the integrity and human dignity of the claimant" either individually or cumulatively. See Framework of Analysis, RefLex (Special Issue: The Definition of Persecution), Sept. 1992, at 12.

76. GUIDELINES, supra note 3 , at 8.

77. The Saudi state does not directly prosecute women for refusing to wear a veil. Rather the quasi-official religious police (Committee for the Promotion of Virtue and Prevention of Vice), known as Muttawi'in deal with it as they see fit with the tacit approval of the state. In Iran, dress restrictions are codified in law and violations are prosecuted as criminal offenses by the state.

78. To choose a non-gendered example, it would be "easy" for an Orthodox Jew to consume a cheeseburger; at another level, forcing her to do so would grotesquely abrogate her freedom of religion. In Pakistan, Ordinance XX of the Pakistan Penal Code declares adherents of the Islamic Ahmaddhiya sect to not be Muslims, and prohibits Ahmadis from engaging in certain religious practices associated with Islam. This makes it effectively impossible for Ahmadis to legally practice their religion. Such a discriminatory law might be described as inherently persecutory, whatever the penalties for disobedience, though the IRB jurisprudence on this issue is mixed. See, e.g. CRDD No. T90-04196, Sultan, Dualeh, I May 1991 (negative); CRDD No. T90-04893, Aulach, Griffith, 18 June 1991 (positive).

79. Gutoetines, supra note 3 , at 3 . 
her ability to access educational facilities, to earn a livelihood, and to function as an autonomous and independent individual..$^{80}$

Another example of legislated discrimination that could be construed as persecutory are Pakistan's Hudood laws. One component of these laws requires that a woman alleging rape corroborate her complaint with the testimony of four male witnesses. Failure to prove that sexual contact occurred without consent leaves the complainant vulnerable to criminal prosecution herself for adultery or fornication. ${ }^{81}$ As Human Rights Watch concludes:

In sum, the Hudood laws affect all citizens of Pakistan, but are applied to women with particularly disastrous effect. Women are discriminated against by law, they find it extremely difficult to prove rape and may face criminal prosecution if they fail to do so. Women who behave in ways their husbands or fathers dislike, or who seek to divorce and re-marry, or who choose to marry against the will of their parents, or who happen to be related to a man wanted by the authorities and thus get wrongly accused of Hudood offenses as a means of intimidating their relatives, all risk criminal prosecution under the Hudood laws, often with no basis in fact. Their male co-defendants in such cases also suffer, although they are better protected by the law and benefit from its biases against women. ${ }^{82}$

An example of a discriminatory policy with a legitimate end pursued through persecutory means might be the one child policy in the People's Republic of China. While the goal of population control may be entirely defensible, one may contend that forced abortions and forced sterilization of women are each persecutory means of accomplishing the objective. As Justice Linden bluntly asserted in his judgment in Cheung, "Brutality in furtherance of a legitimate end is still brutality. ${ }^{183}$

Finally, a scenario where the penalty for noncompliance with a discriminatory law might be disproportionately severe might be illustrated by the Iranian law that makes a woman's failure to wear a chador a criminal law punishable by seventy-five lashes. ${ }^{84}$ Thus, even if one rejected the

80. I prefer this approach over others with respect to dress restrictions. Laws prohibiting women but not men from wandering topless in public seem no less discriminatory than laws requiring men but not women to veil. In my view, what elevates compulsory veiling to persecution is the existence of "a number of discriminatory measures of this type, ... where there is thus a cumulative element involved" UNHCR Handbook, supra note 36 , at I 55 .

81. For a description of the Hudood laws and the consequences for women detained under them, see Human Rights Watch, Double Jeopardy, supra note 57, at 47-94.

82. Id. at 68 .

83. Cheung, supra note 68 , at 323 .

84. See Namitabar v. Canada (MEI), FCTD Action No. A-1252-92, 5 Nov. 1993 (TremblayLamer, J.) 
contention that the discriminatory dress restrictions on Iranian women are inherently persecutory, one might still conclude that the penalty for violation of the rule is disproportionately severe in relation to the infraction. It is the penalty, not the proscription, that constitutes persecution in this example.

\section{State Accountability}

Exposing the gendered harms that women endure may not always be sufficient to sustain a finding of persecution. A well-founded fear of rape, dowry burning, genital mutilation, or domestic violence will only attract the label "persecution" upon the attribution of state responsibility to the conduct. If, as Hilary Charlesworth charges, "rights are defined by the criterion of what men fear will happen to them, ${ }^{85}$ then so too with persecution. Thus, the paradigmatic examples of persecution typically involve the state actively engaging in the proscribed conduct, such as torture of political prisoners.

Discriminatory laws and rape by military or police involve direct participation by, or on behalf of, the state. Conversely, domestic violence, dowry burning, and female genital mutilation are committed by non-state agents ${ }^{86}$ under the penumbra of state condonation, indifference, or impotence. While there is no shortage of episodes where women are directly victimized by state actors, much of the violence committed against women on a global scale-rape, physical abuse, and murder-occurs in the socalled "private" sphere. It is perpetrated by husbands, boyfriends, in-laws, and, in the case of genital mutilation, women in the local community. ${ }^{87}$ As Shelley Wright astutely observes, "for most women, indirect subjection to the State will almost always be mediated through direct subjection to individual men or groups of men." ${ }^{\prime 88}$

The problem for a woman in Dujarie's position lies not in demonstrat-

85. Charlesworth et al., supra note 53 , at 71 .

86. Or state agents acting in a private capacity.

87. Literature on female genital mutilation as a human rights violation has proliferated in recent years, including Alice Walker, Possessing the Secret of Jor (1992) and several documentary and legal accounts, among which are Fran P. Hosken, The Hosken Report: Genital and Sexual Mutilation of Females (3d ed. 1982); Allison T. Slack, Female Circumcision: A Critical Appraisal 10 Hum. RTs. Q. 437 (1988); Robyn Smith, Female Circumcision: Bringing Women's Perspectives into the International Debate, 65 S. CAL. L. Rev. 2449 (1992); Karen Engle, Female Subjects of Public International Law: Human Rights and the Exotic Other Female, 26 New ENG. L. Rev. 1509 (1992). A singularly valuable source of information is President of the Inter-African Committee, Berhane RasWork, Female Genital Mutilation, in Gender lssues and Refugees: Development Implications, Conference Proceedings, supra note 14 , at 1276.

88. Shelley Wright, Economic Rights and Social Justice: A Feminist Analysis of Some Human Rights Conventions, 12 AustL. Y.B. INT'L L. 242, 249 (1992). 
ing that the physical and sexual abuse she suffers constitute serious harm; rather, her task lies in persuading decisionmakers that the Trinidadian state is implicated in the infliction of the harm. The hurdle that Dujarie faces as a refugee claimant encapsulates in microcosm the critique levelled by feminist scholars against the public/private dichotomy in international human rights law. As Hilary Charlesworth writes,

Although the empirical evidence of violence against women is overwhelming and undisputed, it has not been adequately reflected in the development of international law. The great level of documented violence against women around the world is unaddressed by the international legal notion of the right to life because that legal system is focused on "public" actions by the state.

A similar myopia can be detected also in the international prohibition on torture. A central feature of the international legal definition of torture is that it takes place in the public realm: it must be "inflicted by or at the instigation of or with the consent or acquiescence of a public official or other person acting in an official capacity." Although many women are victims of torture in this "public" sense, by far the greatest violence against women occurs in the "private" non-governmental sphere. ${ }^{89}$

Dujarie's challenge is to demonstrate why Canada ought to care about her plight in the same way that it cares about the Trinidadian demonstrator who is beaten by police. It is a truism that refugee law does not protect individuals from "common crimes"; it only protects them from "persecution." The transition from "common crime" to "persecution" turns, in part, on the role of the state in systematically failing to protect the claimant from the feared harm. As Justice La Forest stated in Ward,

International refugee law was formulated to serve as a back-up to the protection owed a national by his or her state. It was meant to come into play only in situations where that protection is unavailable, and then only in certain situations. The international community intended that persecuted individuals be required to approach their home state for protection before the responsibility of other states becomes engaged. ${ }^{91}$

The foregoing implies that, in exchange for obedience, the sovereign owes a national the duty not to violate her rights and a duty to protect her from transgressions by others. As Justice La Forest remarks elsewhere, "[s]ecurity of nationals is, after all, the essence of sovereignty." ${ }^{\text {" } 2}$ Obviously, state protection is absent where the state perpetrates persecution. State

89. Charlesworth et al, supra note 53 , at 72 .

90. The other part of the equation involves understanding the violence as a systematic targeting of women qua disempowered group. See infra discussion "Particular Social Group."

91. Ward, supra note 11 , at 709 .

92. Id. at 725 . 
protection may also falter where the state condones, tolerates, or is simply unable to protect the claimant from the acts of others. Consistent with the dictum in Ward, the Guidelines declare that persecution includes "acts of violence either by public authorities or at the hands of private citizens from whose actions the state is unwilling or unable to adequately protect the concerned persons. ${ }^{\prime 93}$ In situations of domestic violence, state inaction may take the form of official condonation (e.g., marital rape exemptions in law). More often, lack of police response to pleas for assistance, refusal to investigate or prosecute individual cases, and a reluctance to convict or punish indicate that violence against women is legally proscribed, but socially sanctioned. Thus, the failure to protect women from intimate violence represents an uncoordinated yet highly efficient matrix of inertia, consolidated at all loci of the criminal justice system.

The Guidelines' assertion that state failure to protect women from private violence constitutes persecution embodies a fortuitous convergence of refugee jurisprudence, feminist analysis, and evolving norms in international human rights law. The UNHCR Handbook takes the position that "acts by private citizens, when combined with state inability to protect, constitute 'persecution.'"194 In Ward, the Supreme Court of Canada considered the question of state complicity where an Irish claimant feared retaliation from the Irish National Liberation Army (INLA) in circumstances where the police admitted they could not protect him. There was no suggestion in the case that the police cooperated with the INLA or condoned its vendetta against Ward. The Court in Ward endorsed the UNHCR Handbook and ruled unequivocally that "state complicity in persecution is not a pre-requisite to a valid refugee claim. ${ }^{\prime \prime 5}$ As long as the state fails to adequately protect the claimant, it does not matter whether inaction derived from collusion, indifference, or genuine impotence.

In Ward, the court found that where a claim is based on the state's inability to protect a national, the claimant must prove that she sought the protection of the authorities unless it would be "objectively unreasonable" to do so because state protection would not "reasonably have been forthcoming." ${ }^{\prime 96}$ As Justice La Forest states, "it would seem to defeat the purpose of international protection if a claimant would be required to risk his or her life seeking ineffective protection of a state, merely to demonstrate that ineffectiveness. ${ }^{\prime \prime 7}$

93. GUIDELINES, supra note 3 , at 3 .

94. UNHCR Handbook, supra note 36, at ๆ 65.

95. Ward, supra note 11 , at 713 .

96. Id. at 724 (quoting HathaWAY, supra note 1 , at 130 ).

97. Id. 
Ward and its lower court precedents ${ }^{98}$ involved highly visible, politically motivated violence committed by non-state actors. The extension of the principle emerging from Ward to situations of dowry burning, female genital mutilation, and domestic violence require incursion into the socalled "private sphere." At least one Canadian court demonstrated its willingness to move in this direction prior to the Guidelines. The case of Mayers, Marcel v. Minister of Employment and Immigration ${ }^{99}$ involved a fact situation very similar to Dularie's namely, a Trinidadian woman subject to repeated physical and sexual abuse in circumstances of police indifference. The narrow jurisdictional basis for judicial review in the case constrained the scope of the inquiry, but it is significant to note that the Court affirmed an adjudicator's ruling that domestic violence in the absence of state protection could constitute persecution. ${ }^{100}$

Feminist theorists have long deprecated the public/private distinction, pointing out that the refusal of the state to intervene in the "private" sphere of the home only insulates abuse of pre-existing patriarchal power within that sphere, perpetuating and justifying the patriarchal organization of the "public" sphere. ${ }^{101}$ At the international level, the public/private dichotomy replicates itself. Because international human rights law only binds states, liability exists only if states can be held accountable for their failure to protect women from intimate violence. Unfortunately, just as local police are reluctant to intrude into the "private" sphere of the home, the international human rights regime is reluctant to intrude into the "private" sphere of domestic law and law enforcement. Catharine MacKinnon tersely explains the parallel:

In this statist structure, each state's lack of protection of women's human rights is internationally protected, and that is called protecting state sovereignty. A similar structure of insulation between women and accountability for their violations exists domestically. . . This is called protecting the community. ${ }^{102}$

A core component of the "women's rights are human rights" campaign has been validation of the claim that states violate women's international

98. Lower court judgments cited in Ward include Rajudeen v. Canada (Minister of Employment and Immigration) (1985), 55 N.R. 129 (F.C.A.D.) (police unable or unwilling to protect Tamil Muslim from Sinhalese Buddhist mobs); Surujpal v. Canada (Minister of Employment and Immigration) (1985), 60 N.R. 173 (F.C.A.D.) (failure by Guyanese authorities to protect members of the People's Progressive Party from politically motivated violence).

99. (1992), 97 D.L.R.(4th) 729 (F.C.A.D.).

100. Id. at 738-39.

101. A vast body of literature exists on this topic. See Jean Bethike Elshtain, Public Man, Private Woman (1981); Carole Pateman, The Sexual Contract (1988); Katherine O'Donovan, Sexual Divisions in Law (1985); Susan Moller Okin, Justice, Gender and the Family (1989).

102. Mackinnon, supra note 54 , at 15 . 
human rights when they fail to combat violence against women, and these arguments have been eloquently and resolutely voiced by several feminist legal scholars. ${ }^{103}$ The principle recently obtained positive (if unenforceable) affirmation in the UN General Assembly with the adoption of the Declaration on the Elimination of Violence Against Women, ${ }^{104}$ that defined violence against women as "any act of gender-based violence that results in, or is likely to result in, physical, sexual or psychological harm or suffering to women, including threats of such acts, coercion or arbitrary deprivation of liberty whether occurring in public or private life."105 Article 4 of the Declaration exhorts states to inter alia,

condemn violence against women and ... not invoke any custom, tradition or religious consideration to avoid their obligations with respect to its elimination. States should pursue by all appropriate means and without delay a policy of eliminating violence against women ....

The Declaration remains unenforceable as international human rights law. However, developments on the international plane bolster the arguments of refugee claimants, like Dularie, that the state is sufficiently implicated in the harm done to them to constitute persecution within the parameters of the refugee definition.

\section{Prevalence of Gender Persecution}

The Guidelines also attempt to pre-empt objections to labelling various forms of violence against women as persecutory-specifically, the argument that a phenomenon that is widely practiced in a woman's country of origin or around the world could not be deemed to be persecutory. The Guidelines state that:

The fact that violence, including sexual and domestic violence, against women is universal is irrelevant when determining whether rape, and other genderspecific crimes constitute forms of persecution. The real issues are whether the

103. See Dorothy Thomas \& Michele Beasley, Domestic Violence as a Human Rights Issue, 15 Hum. RTs. Q. 36 (1993); Celina Romany, State Responsibility Goes Private: A Feminist Critique of the Public/Private Distinction in International Human Rights Law, in Human Richts of WOMEN, supra note 53, at 85-115; Rebecca Cook, Accountability in International Law for Violations of Women's Rights by Non-State Actors, in ReCONCEIVING Reality: Women and International Law, Studies in Transmational Legal Policy No. 25 93-116 (Dorinda Dallmeyer ed., 1993).

104. GA Res. 48/104 Supp. No. 49, UN Doc. A/48/49 (1993).

105. Articles 1 and 2 explicitly encompass within the term "violence against women," "physical, sexual and psychological violence occurring in the family, including battering, sexual abuse of female children in the household, dowry-related violence, marital rape, female genital mutilation and other traditional practices harmful to women." 
violence-experienced or feared-is a serious violation of a fundamental human right for a Convention ground and in what circumstances can the risk of that violence be said to result from a failure of state protection. ${ }^{106}$

The subtext of this passage suggests that the ubiquity and frequency of gender-specific violence does not detract from its character as persecution. Whether decisionmakers honor the implications of that insight remains to be seen.

Although women everywhere may be constrained by the disciplining menace of gender violence, the requirements for proving a "well-founded" fear of persecution narrow considerably the ambit of those who can qualify as a refugee. The Guidelines explicitly require claimants to establish an individual basis for their fear:

refugee status being an individual remedy, . . . the woman will need to show that she has a genuine fear of harm, that her gender is the reason for the feared harm, that the harm is sufficiently serious to amount to persecution, that there is a reasonable possibility for the feared persecution to occur if she is to return to her country of origin and she has no reasonable expectation of adequate national protection. ${ }^{107}$

Having said that, the Guidelines stipulate elsewhere that:

A gender related claim cannot be rejected simply because the claimant comes from a country where women face generalized oppression and violence and the claimant's fear of persecution is not identifiable to her on the basis of an individualized set of facts. ${ }^{108}$

At first blush, these two directives fit awkwardly together. Closer scrutiny reveals that they are not irreconcilable propositions. The claimant must prove that she has a well-founded fear of persecution as a woman. She cannot, however, automatically succeed on the bare argument that "because I am a woman, I have a well-founded fear of persecution." There are two ways in which she can demonstrate that as a woman, she has a wellfounded fear. First, she can use evidence of her own past persecution. As Hathaway remarks, past persecution is generally a sufficient, but not necessary, indicator of future persecution. ${ }^{109}$ Second, the claimant can point to other "similarly situated" women who have been subject to persecution. For example, a Bosnian Muslim woman who fears rape by Serbian forces

106. Guidelines, supra note 3 , at 7 .

107. Id. at 6 (emphasis in original).

108. Id. at 9. This amounts to a gender-specific renunciation of the "particularized evidence rule," which was first rejected in Salibian v. Canada (Minister of Employment and Immigration), 3 F.C. 250 (1990).

109. Hathaway, supra note 1 , at 88. 
may be able to describe many other women in her region who were raped. However, the indiscriminate nature of rape under the circumstances precludes any prediction that she will be singled out as a target for rape from among other Bosnian Muslim women. In such a case, a Board member may legitimately conclude (using the language of the Guidelines) that the claimant

has a genuine fear of harm, that her gender is the reason for the feared harm, that the harm is sufficiently serious to amount to persecution, that there is a reasonable possibility for the feared persecution to occur if she is to return to her country of origin and she has no reasonable expectation of adequate national protection. ${ }^{110}$

The conclusion will be valid even though the claimant has fled a place where "women face generalized oppression and violence and the claimant's fear of persecution is not identifiable to her on the basis of an individualized set of facts." "11' An even starker case might be an Iranian woman subject to a law requiring her to veil. Assuming that the law is persecutory, a woman will certainly be unable to show that she has been uniquely singled out by this law (it applies to all women), yet she can still argue that she has a wellfounded fear of being persecuted by the application of the law to her.

\section{B. Grounds of Persecution}

Once a woman has cleared the hurdle of proving persecution, she must next establish a nexus between the persecution and the listed grounds of race, religion, nationality, particular social group, or political opinion. As noted earlier, the list does not include gender, and the Guidelines do not add it. Instead, the Guidelines encourage decisionmakers to let gender inform their assessment under race, religion, nationality, or political opinion. As a last resort, "women" (or some subcategory thereof) might qualify as "a particular social group" for purposes of the refugee definition. Bringing women into the Convention refugee definition through the particular social group category was encouraged by the UNHCR Executive Committee in 1985 in Conclusion No. 39, which suggested that "women asylum seekers who face harsh or inhuman treatment due to their having transgressed the social mores of the society in which they live may be considered as a 'particular social group.'"112 While the Guidelines quote Conclusion No. 39 with

110. GUIDELINes, supra note 3 , at 6 .

111. Id, at 8 .

112. Report of the Thirty-Sixth Session of the Executive Committee of the High Commissioner's Programme, 36th Sess., 7-18 October 1985, at 36, UN Doc. ANAC 96/673, qf 115(4)(k). 
apparent approval, ${ }^{113}$ they tacitly promote the grounds of political opinion or religion as superior routes, asserting that

[m] lost of the gender-specific claims involving fear of persecution for transgressing religious or social norms may be determined on grounds of religion or political opinion. Such women may be seen by the governing authorities or private citizens as having made a religious or political statement in transgressing those norms of their society, even though UNHCR Conclusion No. $39 \ldots$ contemplates the use of particular social group as an appropriate ground.114

\section{Race}

The UNHCR Handbook advises that for purposes of the refugee definition, race "has to be understood in its widest sense to include all kinds of ethnic groups that are referred to as 'races' in common usage."115 The Guidelines observe that race and sex may operate in tandem to explain why a claimant fears persecution:

There may be cases where a woman claims a fear of persecution because of her race and her gender. For example, an Asian woman in an African society can be persecuted not only for her race, but also for her gender. ${ }^{116}$

What remains unclear from this example is whether the Guidelines advocate reliance on race exclusively (rather than in tandem with a gender based social group) as the grounds for persecution.

\section{Religion}

The Guidelines point out that freedom of religion denotes not only the right to practice, but also the right not to practice a religion. Thus, a violation of the negative freedom of religion might also constitute persecution:

A woman who in an Islamic society, for example, chooses not to subscribe to or follow the precepts of a state religion may be at risk of persecution for reasons of religion. In the context of the Convention refugee definition, the notion of religion may encompass, among other freedoms, the freedom to hold a belief system of one's choice or not to hold a particular belief system and the freedom to practise a religion of one's choice or not to practise a prescribed religion. In certain states, the religion assigns certain roles to women; if a woman does not

113. See Guidelines, supra note 3 , at 5 .

114. Id. at 5 (emphasis in original).

115. UNHCR Handbook, supra note 36 , at If 68.

116. Guidelines, supra note 3 , at 4 . 
fulfil[1] her assigned role and is punished for that, she may have a well-founded fear of persecution for reasons of religion. ${ }^{117}$

The application of this proviso to Nada's case is fairly straightforward. By refusing to follow the practices of Islam as dictated by the state, Nada's freedom not to practice a prescribed religion (or, more correctly, a prescribed version of it) has been violated. ${ }^{118}$

\section{Nationality}

The UNHCR Handbook takes a broad view of nationality, including within it "membership of an ethnic or linguistic group."119 As such, the scope of "nationality" may overlap with "race." In addition, some states deprive women (but not men) of their formal citizenship if they marry foreign nationals. While nationality laws of this nature are discriminatory, the Guidelines state that "[w] hat would constitute good grounds for fearing persecution is not the fact of losing her nationality as such . . . but the consequences she may suffer as a result." ${ }^{\prime 20}$

\section{Political Opinion}

The Guidelines subsequently provide that the same state practice that constitutes persecution on grounds of religion might also qualify as persecution for reasons of political opinion. As a general matter, a "woman who opposes institutionalized discrimination of women, or expresses views of independence from male social or cultural dominance in her society, may be found to fear persecution for reasons of imputed political opinion." 121

With respect to oppression in a patriarchal theocracy, the Guidelines offer decisionmakers the option of characterizing the persecution as political as well as religious:

The political nature of oppression of women in the context of religious laws and ritualization should be recognized. Where tenets of the governing religion in a given country require certain kinds of behaviour exclusively from women, contrary behaviour may be perceived by the authorities as evidence of an

117. Id. (emphasis in original).

118. See infra discussion "Cultural Relativism and Gender Persecution."

119. UNHCR Handbook, supra note 36 , at If 74 .

120. Guidelines, supra note 3, at 4. For an illuminating analysis of the detrimental impact of discriminatory nationality laws on women and their children, see Note, The Right to Have Rights: Gender Discrimination in Nationality Laws, 77 MINN. L. Rev. 195 (1992).

121. GUIDELINES, supra note 3 , at 4 . 
unacceptable political opinion that threatens the basic structure from which their political power flows. ${ }^{122}$

The Guidelines' suggestion that resistance to patriarchy might be a political act is both radical and remarkable.

The Guidelines also alert decisionmakers that "where women are 'assigned' a subordinate status and the authority exercised by men over women results in a general oppression of women," ${ }^{\prime 23}$ women's political protest and activism may be manifest in forms that differ from the familiar modes expressed by men. For instance, a refusal to wear the veil in a fundamentalist Islamic state, or setting up communal kitchens and cooperative nurseries under the fascist Pinochet regime, could all be seen as distinctly womanist brands of political resistance, ${ }^{124}$ and may be treated as such by authorities in the home state, even if they do not conform to the types of political activism most commonly displayed by men. ${ }^{125}$

\section{Social Group}

Using race, religion, nationality, and political opinion as grounds for persecution permit the decisionmaker to accept a claim without explicitly acknowledging that the claimant's gender was a reason for the persecution. When the fact situation obstinately resists the attempt to avoid specific reference to gender, the Guidelines advise decisionmakers to consider the residual category of "particular social group." The scope of this category as a basis for persecution has been long contested in Canadian lower courts and elsewhere. ${ }^{126}$ The Guidelines do not engage that debate, though they do highlight the family as an example of a particular social group that is more or less noncontroversial in Canadian jurisprudence. ${ }^{127}$ According to Hathaway, "whenever there is an indication that the status or activity of a claimant's relative is the basis for a risk of persecution, a claim grounded in

122. Id. (emphasis in original).

123. Id. (emphasis in original).

124. See Greatbatch, supra note 9 .

125. Human Rights Watch reports that in Peru, "[a]t times, the violence takes gender specific forms, as in the security forces' use of rape against women. At other times, the victim's gender does not influence the form of the abuse, but affects its motivation, as in the Shining Path's execution of community activists who are women." HUMAN RIGHTS WATCH, UnTOLD TERROR, supra note 57 , at 58.

126. For a summary of some of the main competing views, see HathaWAY, supra note 1 , at $157-61$.

127. Several Federal Court and CRDD decisions have considered the family to constitute a particular social group: Al Busaidy v. Canada (MEI), (F.C.A.) [1992] F.C.J. No. 26, Appeal No. A-46-91; Astudillo v. MEl (1979), 31 NR 121 (FCA); Hristova, Adelina Ivanova et al. v. MEI, [1994] F.C.J. No. 132, Action No. A-487-92 (FCTD). 
family background is properly receivable. ${ }^{1128}$ Recognition of the family as a social group can be crucial in situations where women are threatened, harassed, and victimized, either as a means of 'punishing' the man by violating his female kin, or because the political opinions of their male relatives are imputed to the women. Indeed, women's identities, beliefs, and status are frequently subsumed under those of their male kin. Thus, it seems reasonable to infer that a woman's kinship association with men could precipitate her persecution on the basis of imputed political opinion regardless of what she herself believes.

The Ward decision, following close on the heels of the Guidelines, deals extensively with the definition of "particular social group." For many years, the recurring theme in the commentary has been a struggle between two alternatives. The "restrictive" definition would require that a "particular social group" be united by some religious, political or national affiliation. The end result of this approach would be to render the category of "particular social group" otiose, because any individual member of a social group so defined would also be able to make a claim based on religion, nationality, or political opinion. ${ }^{129}$ The "liberal" approach advocates the use of "particular social group" as a safety net which, according to Arthur Helton, "could include all the bases for and types of persecution which an imaginative despot might conjure up." ${ }^{\prime 130}$

In Ward, the Supreme Court of Canada concluded that this latter formulation "essentially characterizes an association of people as a 'particular social group' merely by virtue of their common victimization as the objects of persecution."131 The putative hazard of this approach would be that it obviates the need to enumerate any grounds of persecution. The requirement that persecution occur because one is a member of a particular social group becomes tautologous if social groups could be constituted through the common experience of persecution: one fears persecution because one is a member of a particular social group consisting of persecuted people. Using the intention of the drafters as the vehicle for his conclusion, Justice La Forest writes:

Although the delegates [who drafted the Convention] inserted the social group category in order to cover any possible lacuna left by the other four groups, this

128. Hathaway, supra note 1 , at 165-66.

129. As Justice Urie noted in Canada (Attorney-General) v. Ward, 2 F.C.A. 667 (1990).

130. Arthur Helton, Persecution on Account of Membership in a Social Group as a Basis for Refugee Status 15 Col. Hum. Ris. L. Rev. 39, 45 (1983) (quoted in Ward, supra note 11, at 729 ).

131. Ward, supra note 11, at 729. Justice La Forest was responding both to Professor Helton and to Isi Foighel, The Legal Status of the Boat People, 48 Nord. TIOS. For INT'L Ret. 217, 222-23. 
does not necessarily lead to the conclusion that any association bound by some common thread is included. If this were the case, the enumeration of these bases would have been superfluous; the definition of "refugee" could have been limited to individuals who have a well-founded fear of persecution without more. The drafters' decision to list these bases was intended to function as another built-in limitation to the obligations of signatory states. ${ }^{132}$

Rather than steer in the direction of the traditional restrictive position, however, Justice La Forest finds a limiting principle for "particular social group" in the notion of anti-discrimination. Noting that the categories of race, religion, nationality, and political opinion also figure prominently in international and domestic human rights law, Justice La Forest considers it "appropriate to find inspiration in discrimination concepts." ${ }^{133}$ Justice La Forest reviews academic commentary, ${ }^{134}$ lower court decisions from Canada ${ }^{135}$ and the United States, ${ }^{136}$ and jurisprudence around the equality provision of the Canadian Charter of Rights and Freedoms. ${ }^{137} \mathrm{He}$ then proposes a "social group" taxonomy that embraces three alternative classes:

(1) groups defined by an innate or unchangeable characteristic;

(2) groups whose members voluntarily associate for reasons so fundamental to their human dignity that they should not be forced to forsake the association; and

(3) groups associated by a former voluntary status, unalterable due to its historical permanence. ${ }^{138}$

For present purposes, the most important fact is that Justice La Forest cites gender, along with linguistic background and sexual orientation, as examples under the first category. ${ }^{139}$ Recognition of gender as the basis for

132. Ward, supra note 11 , at 732 .

133. Id. at 734 .

134. Id. at 728-31.

135. Id. at $735-36$.

136. Id. at 736-37. The Court relies in particular on Matter of Acosta, I.A.B., Interim Decision 2986, 1 Mar. 1985.

137. Id. at 738. Section 15(1) of the Charter states that "lelvery individual is equal before and under the law and has the right to the equal protection and equal benefit of the law without discrimination and, in particular, without discrimination based on race, national or ethnic origin, colour, religion, sex, age or mental or physical disability." Canadian Charter of Rights and Freedoms, Constitution Act, 1982, R.S.C. 1985, Appendix II, No. 44, Schedule B, Pt. I. Enacted by the Canada Act 1982 (U.K.), c. 11. As amended by the Constitution Amendment Proclamation, 1983, SI/84-102, Schedule, in force 21 June 1984.

138. Ward, supra note 11, at 739.

139. Id. He gives human rights activists as an example of the second, and fails to give an example of the third, though in the course of his application of the test to the facts in Ward, he finds that the INLA does not qualify under (3). 
social group ascription confirms the stance of the Guidelines and displaces the Federal Court of Appeal's restrictive ruling in Ward, that particular social groups must contain "members . . . united in a stable association with common purposes." ${ }^{140}$ It also effectively overrules at least one CRDD decision where the panel found the category "women" too amorphous to constitute a "particular" social group. ${ }^{141}$

Linking the concept of "particular social group" to general principles of anti-discrimination and Section 15 of the Charter places the classification of women as a particular social group in the realm of the incontrovertible. After all, if the existence of sex discrimination is as much beyond serious debate as racism, how could anyone object to recognizing persecution on grounds of gender when the Convention definition already does so for race? ${ }^{142}$

This recognition of women as a social group is especially valuable in cases where women claim refugee status because of the absence of state protection from domestic violence. By definition, all victims of crime experience a failure of state protection, yet victims of crime do not qualify as refugees per se. What distinguishes women in Dularie's situation is that the nature of the abuse and the chronic failure of state protection evince and sustain the unequal status of women in society. Both the violence committed against women in the home and the ineptitude of the state in combatting the phenomenon are systemic, systematic, and emerge out of the deeply rooted subordination of women. In its report entitled Violence Against the Women in the Family, the UN Centre for Social Development and Humanitarian Affairs surveyed a wealth of literature and came to the following conclusion about the causes of domestic violence:

In sum, it would appear that there is no simple explanation for violence against women in the home. Certainly, any explanation must go beyond the individual characteristics of the man, the woman and the family and look to the structure of relationships and the role of society in underpinning that structure. In the end analysis, it is perhaps best to conclude that violence against wives is a function of the belief fostered in all cultures, that men are superior and that the women

140. Ward (FCA), supra note 127, at 689 (per MacGuigan J., dissenting on other grounds).

141. [1992] CRDD No. 318, No. T92-03227 (18 Nov. 1992) (Davis \& Woloschuk, J.J.). The claimant was an Ecuadoran woman who had been repeatedly brutalized by her husband. The police refused to protect her. The tribunal determined, inter alia, that women did not constitute a particular social group.

142. Celina Romany makes a parallel point about international human rights law when she states that "a feminist critique must ask why white supremacy belongs to lthe internationall community and male supremacy belongs to the individual state." Celina Romany, State Responsibility Goes Private: A Feminist Critique of the Public/Private Distinction in International Human Rights Law, in Human RigHTS of WOMEN, supra note 53 , at $89-90$. 
they live with are their possessions or chattels that they can treat as they wish and as they consider appropriate. ...

The collected scholarship that seeks to explain violence against women in the home indicates that the explanation is complex and certainly multi-factorial. Any explanation must, however, be seen against a background of gender inequality, wherein the victim of such violence is most often the woman and perpetrator most often the man and wherein the structures of society-be they economic, political or legal-act to confirm this inequality. ${ }^{143}$

Perhaps an apt way of restating the report's conclusion is to depict the position of women in the national community as "not just precarious," because "there is also an element of fundamental marginalization which distinguishes them from other persons at risk of serious harm."144 That is to say, women as a group manifest the qualities that Hathaway describes as constitutive of refugees as a category.

Though Ward's anti-discrimination focus provides a cogent rationale for the inclusion of women as a particular social group, it offers no clues about whether or how to delineate the boundaries of a gender-defined social group in a given case.

When a woman is threatened with "dowry burning," or battered by her spouse, or forced to enter an arranged marriage, or faces the prospect of genital mutilation, the grounds of religion or political opinion will likely prove inapposite to her refugee claim. In cases where neither law nor religion dictate the measures in question, yet state protection is not forthcoming, classifying women as a particular social group category may be the claimant's only option. For, as Lori Heise explains, "[i]n all these instances, women are targets of violence because of their sex. This is not random violence; the risk factor is being female." 145

In Dularie's case, where a Trinidadian woman is abused by her male partner in a context of state indifference, the Guidelines accept that her gender may form the basis for social group ascription, but they evade the important question of how to circumscribe the group. In theory, the social group could simply be "women," "Trinidadian women," "Trinidadian women with male partners," or "Trinidadian women subject to wife abuse," because all persons in this category are vulnerable to the type of persecution. In Mayers and Marcel v. MEl, ${ }^{146}$ a case decided by the Federal Court of

143. Centre for Social Development and Humanitarian Affairs, Violence Against Women in the Family 33 (1989) (emphasis added) [hereinafter Violence Against Women in the Family].

144. Hathawav, supra note 1, at 135.

145. Lori Heise, Crimes of Gender, 2 Worlowatch 12 (1989), cited in Guidelines, supra note 3 , at 15 n.10.

146. Mayers \& Marcel v. MEI, supra note 99. 
Appeal prior to the Guidelines, the Federal Court of Appeal ruled that there was some evidence upon which a tribunal might find that the appellant belonged to a social group comprised of "Trinidadian women subject to wife abuse." The Federal Court of Appeal's precedent in Mayers doubtless influenced the panel's approach in the subsequent case of a Zimbabwean girl forced into a polygamous marriage with an abusive husband. The panel defined the particular social group to which she belonged as "unprotected Zimbabwean women or girls subject to wife abuse."147

However one defines the particular social group, the number of women included in it will likely be sizable. The Guidelines emphasize that, just as the prevalence of domestic violence is irrelevant to its character as persecution, so to is the size of the social group irrelevant to the question of whether the designated class is a "particular social group." Yet, the Guidelines tacitly endorse the trend toward limiting the size of the group as much as possible:

[t] the fact that the particular social group consists of large numbers of the female population in the country concerned is irrelevant-race, religion, nationality and political opinion are also characteristics that are shared by large numbers of people.

[W] hat is relevant is evidence that the particular social group suffers or fears to suffer severe discrimination or harsh and inhuman treatment that is distinguished from the situation of the general population, or from other women.

[A] sub-group of women can be identified by reference to the fact of their exposure or vulnerability for physical, cultural or other reasons, to violence, including domestic violence, in an environment that denies them protection. These women face violence amounting to persecution, because of their particular vulnerability as women in their societies and because they are so unprotected. ${ }^{148}$

This construction of a sub-group of women along the lines of "women from country $X$ who are subject to wife abuse" raises several problems. First, it contains the requirement of past persecution in the definition of the social group, despite the general and well-accepted principle in refugee jurisprudence that past persecution is not a prerequisite to establishing a well founded fear of persecution. ${ }^{149}$ Second, defining a group by reference to the common experience of a particular form of persecution is tautological. Finally, it is evasive and misleading to refer to a sub-group of women (such as "battered Trinidadian women") who face persecution because they are

147. CRDD No. U92-06668, supra note 67.

148. GUIDELINES, supra note 3 , at 6 (emphasis in original).

149. See Hathaway, supra note 1 , at 87 . 
women and because they are so unprotected. It is because they are women that they are so unprotected. In other words, to say that one is a woman is to say that one is vulnerable to abuse committed with impunity in the "private" sphere. ${ }^{150}$ Thus, it should not be necessary to go further than to describe the category as "women" simpliciter. Indeed, this appears to be the import of Ward. Justice La Forest lists gender without qualifiers or adjectives as the basis of social group ascription because it is an innate or unchangeable characteristic; one could not describe "women-who-are-subject-towife-abuse" as an innate or unchangeable characteristic. More importantly, when one applies principles of anti-discrimination, it seems more sensible to describe groups in terms of vulnerability to persecution in general, rather than in terms of vulnerability to a particular type of persecution. To the extent that Ward contemplates gender as a category, it may be that this aspect of the Guidelines has been effectively superseded by the dictum of the Supreme Court of Canada.

Having said this, designating "women" as the appropriate social group does not lead inexorably to the consequence that all women are automatically entitled to refugee status. As noted earlier, whether the basis of the persecution is membership in a particular social group or some other ground, a claimant will still be required to show that she genuinely fears persecution and that her fear is objectively "well-founded." How this will play out in practice can only be a matter of speculation at present. Where the claim is centered on the failure of state protection, the fact that the claimant is a woman, in a culture where the statistical odds of her being abused are significant, may well be treated as insufficient to establish a genuine fear of serious harm and/or a reasonable possibility of future harm. In any event, the prevalence of violence against women in the claimant's country of origin will make it all the more likely that the claimant has, in fact, experienced the maltreatment she fears. On the other hand, where the claimant flees the prospect of genital mutilation, or dowry burning, it would

150. Pamela Goldberg defends the "women who are battered and have no recourse to state protection" formulation on the basis that "[i]n most instances, if that same woman were assaulted on the street by an unknown assailant she would receive police assistance and could, if the assailant were found, prosecute him in criminal court for his violence. Rather, it is because her attacker is her husband, boyfriend, or other male intimate that the state is refusing to grant her protection. This makes her vulnerable not because she is a woman, but because she is a woman who is prey to a male intimate." Goldberg, supra note 13, at 597-98. Goldberg's explanation rationalizes rather than resolves the dilemma of incorporating past persecution into the definition. At most, the fact that her attacker is her male partner enhances the well-foundedness of her fear of future abuse. Moreover, her speculation on the protection available to women assaulted by strangers is pure conjecture, and might actually be wrong whenever sexual assault is at issue. Finally, it is not clear what motivates the narrow definition of a social group. After all, race, religion, nationality, and political opinion are all broadly defined groups. 
be absurd to require that she have experienced the persecution she flees in order to validate her apprehension as "well-founded."

\section{Procedural Issues}

As in other juridical fora, women who base their claim on past incidents of sexual abuse may be confronted with attacks on their credibility or moral rectitude. Other factors complicate the situation for women refugee claimants, some of which the Guidelines address. The Guidelines begin with the general proposition that women refugee claimants "face special problems in demonstrating that their claims are credible and trustworthy." ${ }^{151}$ Members are advised to familiarize themselves with the UNHCR Gender Guidelines, which contain greater detail on gender-sensitivity in a cross-cultural context. For example, the UNHCR Gender Guidelines counsel interviewers to

Be aware of gender differences in communication, particularly regarding nonverbal communications. As an interviewer, avoid intimidating gestures that inhibit responses. In assessing the credibility of the female applicant, for example, do not judge it on the basis of such Western cultural values as the ability to maintain eye contact. ${ }^{152}$

The Canadian Guidelines observe that "[w]omen from societies where the preservation of one's virginity or marital dignity is the cultural norm may be reluctant to disclose their sad experiences of sexual violence in order to keep their shame to themselves alone and not dishonor their family or community," and may exhibit symptoms consistent with rape trauma syndrome. ${ }^{153}$ The UNHCR Gender Guidelines advise interviewers to give time and space to the woman applicant, so that she may develop a rapport with the interviewer that will enable her to recount her experiences.

Interviewers are advised not to ask for details of sexual abuse-" the important thing in establishing a well-founded fear of persecution is to establish that some form of it has occurred." 154 Also, the UNHCR Gender Guidelines caution that sexual assault survivors may exhibit symptoms consistent with rape trauma syndrome and should be treated with sensitivity. The UNHCR Gender Guidelines explain that the symptoms can include

151. Gubelines, supra note 3 , at 9 .

152. UNHCR GENDER Guidelines, supra note 10 , at श 72.

153. Guideunes, supra note 3 , at 9. The stigma described in the Guidelines is probably a matter of degree rather than kind. Certainly Anglo-European culture stigmatizes women who allege that they were sexually assaulted.

154. UNHCR Gender GuIDeLINES, supra note 10 , at If 72. 
"persistent fear, a loss of self-confidence and self-esteem, difficulty in concentration, an attitude of self-blame, a pervasive feeling of loss of control, and memory loss or distortion," 155 none of which should be misconstrued as proof of non-credibility. The Guidelines also raise the possibility of providing claimants with the option of presenting their evidence by affidavit, videotape, or before members specially trained in dealing with violence against women, though this has not been implemented to date.

A final observation in the Guidelines, about proving gender-specific persecution, concerns the dearth of documentary evidence about country conditions relevant to women's situations. Country reports about the general human rights situation from sources such as the US State Department, Human Rights Watch, and Amnesty International are frequently published, but until recently have not addressed gender-related persecution. The Guidelines caution decisionmakers that, where "a gender-related claim involves threats of or actual sexual violence at the hands of authorities (or private citizens not susceptible to state control), the claimant may have difficulties in substantiating her claim with any 'statistical data' on the incidence of sexual violence in her country of origin." 156

The UNHCR Gender Guidelines suggest that the "recruitment and training of female interpreters is a precondition for the most effective interviewing. ${ }^{\prime 157}$ The importance of having competent and sensitive decisionmakers cannot be overstated-at least one unsuccessful refugee claim was quashed on judicial review because of the sexist bias and demeaning behaviour displayed by the panel toward a female Somali claimant. ${ }^{158}$ All of this only evinces the reality that the Guidelines are words on paper, and words can only be translated into deed by willing interpreters.

\section{Flaws and Gaps in the Guidelines}

While the Guidelines attempt to be comprehensive in their treatment of the relevance of gender, certain significant omissions remain that could undermine the success of genuine claimants.

On the substantive side, the "internal flight alternative" rule (a standard in refugee determination) stipulates that if a claimant could have avoided

155. Id.

156. GUIDELINES, supra note 3 , at 8.

157. UNHCR Gender Guidelines, supra note 10, q 41.

158. Yusuf v. Canada (Minister of Employment and Immigration), [1992] 1 F.C. 629, 133 N.R. 391 (F.C.A.). 
persecution by moving to another part of her country of origin, she is not a refugee from that country. ${ }^{159}$ The Guidelines instruct decisionmakers to take into account the possibility of internal flight as an effective recourse when assessing the validity of the claimant's fear of persecution, ${ }^{160}$ but they do not elaborate. There is a danger that some decisionmakers may conclude that a woman who was beaten by her husband and could not obtain police protection, or who was being forced into a marriage she did not want, simply could have moved to another region of her country and need not have fled to Canada. This may be an option in some countries and in some cases, but not in others. Evidence about the social or physical impossibility of women living safely apart from their husbands and kin in their countries of origin may be necessary to counteract potentially adverse assumptions about the practical availability of the internal flight alternative.

Another basis upon which one may be denied refugee status is cessation due to change of circumstances. ${ }^{161}$ If the conditions giving rise to the persecution in the country of origin have been resolved since the claimant fled and protection is now viable in the refugee's country of origin, the claim may be denied. However, a refugee claimant can still respond that she continues to suffer the effects of past persecution, and argue that there exist "compelling reasons" not to apply the cessation clause to her. The Guidelines do not mention cessation at all and thus do not offer any advice to decisionmakers on the gendered aspects of the effects of a compelling reasons" defense to a cessation determination.

One hypothetical illustration where this might be germane is in the case of survivors of the systematic rape of women from opposing ethnic or religious groups in the former Yugoslavia. Suppose a Muslim survivor of rape by Serb militia manages to make it to Canada and launch a refugee claim. Before her claim is adjudicated, the war is settled and her region is no longer under occupation. Should the cessation clause apply? Arguably, it would be highly relevant to consider that Muslim women, who have been sexually assaulted by enemy forces, may be ostracized by members of their own family, faith, and community because they have been "defiled." Even though the risk of further persecution is ostensibly eliminated, the stigmatization of a survivor by her own people might eliminate any real prospect of reintegrating into that society. Thus, the effects of past sexual persecution might furnish a compelling reason why some women's ability to return to

159. See Hathaway, supra note 1, at 133-34 and cases cited therein.

160. Guidelines, supra note 3 , at 10.

161. Immigration Act, $\$ 2(2)(e)$. 
their community distinguish them from male claimants who have been persecuted in different ways. ${ }^{162}$ By failing to consider the way gender affects both the availability of the internal flight alternative and the ability of sexually abused women to return to their communities, the Guidelines leave gaps that have the potential of being filled with sexist assumptions that ultimately subvert the spirit and intent of the Guidelines.

On the procedural side, although the Guidelines refer to the possibility that "women who have suffered domestic violence may also be reluctant to testify," they do not advert to the explanation that the perpetrator might also be claiming refugee status. The Convention Refugee Determination Rules ${ }^{163}$ require that refugee claims of spouses be processed jointly unless one of the parties applies for severance and provides reasons. As David Matas contends, the advantage of joinder is efficiency, but there is also a danger that the woman's claim will be submerged in the claim of her husband, with the result that "there is a tendency for claims of the whole family to succeed or fail based on the success or failure of the claim of the husband." 164

The problem becomes acute where the woman has a separate, genderspecific aspect to her claim. If the male claimant has abused his wife, she will be unable to raise it in a joint hearing for obvious reasons. Even where a woman has been the victim of sexual abuse by others, she may be reluctant to disclose the incident(s) in front of her husband, if he does not know, or he may not wish her to reveal it for fear of being "shamed." While the woman can request severance, she will be obliged to supply reasons, which might consist of the very information she or her husband wish to suppress. ${ }^{165}$ The Guidelines are silent on this issue; Matas recommends that a rule of automatic severance of claims with the option of joinder would offer better protection to married women making refugee claims.

162. In CRDD No. 15, No. C91-00123 (12 Feb. 1992) (E.D. Pask \& J. Lo), the panel determined that "a well founded fear of persecution from the Guatemalan military no longer exists because of the claimant's political opinion or her membership in a particular social group, that is, the family of V.H." The panel took into account, however, the traumatic events experienced by the claimant (raped at fifteen by guerrillas in the presence of her mother and a nephew, mother forced to serve as a guide for guerrillas, friends and family members killed by military or guerrillas) and found it understandable that the claimant would "believe that she is at risk forever because of the minute amount of knowledge that she has." The panel concluded that the claimant had "compelling reasons arising out of previous persecution" for refusing to avail herself of the protection of Guatemala, and thus had not ceased to be a refugee.

163. Registration SOR/93-45, 28 Jan. 1993, C. Gaz. Pt. II, Vol. 127, No. 3, Rule 10.

164. David Matas, Gender and Refugee Law, Gender Issues and Refugees: Development Implications, Conference Proceedincs, supra note 14 , at 1003, 1010.

165. Id. at 1012 . 


\section{REPRESENTING GENDER PERSECUTION}

Debates about the Guidelines tend to elicit two lines of objection: the Guidelines either go too far in imposing "Western"166 values on other cultures, or "don't go far enough" because they fail to add gender explicitly to the refugee taxonomy. The former argument often deploys "cultural imperialism" as its vehicle, while the latter articulates a feminist concern about the adequacy of the interpretive strategy adopted by the Guidelines. This section considers both of these critiques and adds a third concern about the potential friction generated when feminist discourse is grafted onto refugee discourse.

\section{A. Cultural Relativism and Gender Persecution}

The Guidelines invoke a variety of international legal instruments, prohibiting sex discrimination and guaranteeing equal status to men and women to deflect the rhetorical queries of critics, such as Bernard Valcourt, who was Minister of Employment and Immigration at the time the Guidelines were issued. Valcourt initially resisted the calls to recognize gender persecution as the basis of a refugee claim by invoking the spectre of cultural imperialism:

But will Canada act as an imperialist country and impose its values on other countries around the world? ... I don't think that Canada should unilaterally try to impose its values on other countries regarding laws of general application. ${ }^{167}$

Stripped of its rhetorical flourish, Valcourt's argument effectively asserts that the legal institutions of Canadian patriarchy ought to respect the patriarchical customs and laws of other states. ${ }^{168}$ In response to this line of objection, the Guidelines incorporate international norms to bolster the proposition that characterizing certain forms of sex-based discrimination

166. I use the term "Western" advisedly and metaphorically. It connotes an East/West ideological split which strikes me as inaccurate; the "North/South" dichotomy is also problematic, however, insofar as it is organized along an economic gradient which is presumed to carry cultural connotations as well.

167. Quoted in Estanislao Oziewicz, No Plan to Accept Victims of Sex Bias, The Globe and MAlL, 16 Jan. 1993, at A6.

168. Perhaps the unarticulated corollary was that other states ought to extend the same deference to Canadian manifestations of patriarchal oppression. For a provocative discussion of the issue of cultural relativism, see Bronwyn Winter, Women, the Law, and Cultural Relativism in France: the Case of Excision, SiGns 939 (Summer 1994). 
and oppression as persecution represents not only Canada's view, but also that of the international community. If a Kurd comes to Canada claiming that he was whipped by Iraqi police interrogators for his political activities, Canada does not consider whether whipping is a time honored tradition in the man's country of origin, or whether the assertion of Kurdish nationalism is against the law in Iraq. Canada does not worry about offending the sensibilities of states that flog people because of their ethnicity or political opinions when Canada declares that the claimant was persecuted. Chair Mawani notes: "This is not simply a matter of imposing western standards on other countries. It is a matter of respecting internationally accepted human rights standards." 169 Though foreign policy considerations often pollute the refugee determination process, ${ }^{170}$ as a matter of principle, refugee law proceeds from the ineluctable fact that states will necessarily draw judgments about the way other states treat their nationals, including women nationals.

It is important to recognize that reliance on international standards cuts both ways. As the Guidelines state in relation to discrimination, a "woman's claim to Convention refugee status cannot be based solely on the fact that she is subject to a national policy or law to which she objects." ${ }^{171}$ The conduct must violate international standards of human rights which, among other things, tend to represent the views of an elite group of first world men about what constitute fundamental human rights. ${ }^{172}$

In Nada's case, then, it should not matter that the Saudi government takes the position that proscribing women's dress and conduct is integral to its conception of Islam, if Nada experiences these laws as oppressive and international norms supply "objective" validation of her subjective experience of persecution. One can envisage "similar results when genital mutilation or dowry burning are submitted to scrutiny.

While this approach seems tidy enough, the issue is both simpler and more complicated than the Guidelines acknowledge. On the one hand, no

169. Immigration and Refugee Board, "News Release," 9 Mar. 1993. The use of international standards is problematic however, in that not all countries have ratified them (especially the "problem countries") but also because they represent at best a consensus among powerful people (usually men) about what constitutes a violation of a fundamental human right, and may ignore the experience of oppression of those with no voice to express themselves or make themselves heard.

170. "Because a finding that the claimant faces a risk of persecution is perceived to imply censure of the state of origin, there is always a risk that concern for the protection of refugees may be subordinated to foreign policy concerns." Hathawar, supra note 1 , at 82.

171. GUIDELINES, supra note 3 , at 8 .

172. CEDAW and the recent Declaration on Elimination of Violence Against Women are possible exceptions. 
question of imposing Western values on other countries need arise at all, because the recipient country plays a relatively passive role in asylum claims. Individuals arrive on Canada's doorstep (figuratively or literally) asking for admission, and Canada says yes or no. A positive decision entails no consequences for the country of origin. Declaring a woman to be a refugee from Saudi Arabia is not tantamount to dispatching troops to Saudi Arabia to compel it to revise its laws, policies, or practices. A finding of refugee status does not reverberate in the official domain of international human rights law. At best, countries are embarrassed when their citizens are recognized as refugees elsewhere. Mostly, they are indifferent, dismissive, or disdainful.

In sum, accusations of cultural relativism from state to state need not be daunting. After all, why should Saudi Arabia's explanation about why it treats women in a given way occupy a privileged position over Nada's own experiences of that treatment? Similarly, the argument that Western feminists falsely universalize their own "gynocentrism" by supporting Nada's claim lacks credibility. Many women may endorse the normative basis of laws regulating their dress and comportment, and not experience the restrictions as persecutory; still others don the veil as part of an anti-colonialist strategy of protest and resistance. ${ }^{173}$ Nevertheless, it remains that this woman felt persecuted by Saudi restrictions and has come forward saying so. The lively debate among feminists about differences across cultures, about the perils of imposing "Western" notions of feminism on the experiences of other women, and about how international human rights law should be reconfigured-if at all-to account for this, do not impinge directly on the refugee determination process.

Of greater concern to me, however, is the possible appropriation of Nada's experience in ways that subvert her own self-understanding as an Arab, Muslim woman. The media coverage of Nada's plight, though sympathetic to her, inevitably (if unwittingly) played to negative stereotypes about Islam and Arab culture. According to her lawyer, Nada herself was dismayed and alienated by this depiction of her religion and her culture in this way. While it is true that she opposed the totalizing rendition of Islam imposed upon her by the Saudi government and its agents, it is far from evident that she saw misogyny in Islamic practice or Arab culture as either

173. See Lama Abu-Odeh, Post-Colonial Feminism and the Veil: Considering the Differences, 26 New ENG. L. Rev. 1527 (1992); Arlene McLeod, Hegemonic Relations and Gender Resistance: The New Veiling as Accommodating Protest in Cairo, 17 SIGNS 533 (1993); Nayereh Tohidi, Gender and Islamic Fundamentalism in THRo WORLD WOMEN and the Poutics of Feminism 251-65 (Chandra Mohanty et al. eds., 1991). 
inherent or inexorable. There are many Muslim feminists who believe otherwise, ${ }^{174}$ and through internal critique and interpretation refuse to "internalize an absolute version of the majority religion, which cannot admit that it is a negotiated mistranslation." 175 In this they are similar to committed Jewish and Christian feminists, or Catholic lesbians and gays. The reference here is to people whose self-definition might strike outsiders as oxymoronic because they reject the sexism or heterosexism of their religious faith as essential, and prefer to understand it as the artifact of patriarchal heterosexist power relations.

The point is that the Muslim Arab woman remains both Muslim and Arab even as the refugee determination system abstracts her gender identity in order to define her as a victim of persecution. If one accepts the contemporary insight that identity is fragmented, then it follows that every individual must be characterized differently in terms of power relations, depending on the feature under scrutiny. ${ }^{176}$ For the refugee determination process (or the media or Western feminists) to construct Nada as a victim of Islam, or a victim of Arab culture, strikes me as an alienating message that pits Nada qua woman against Nada the Arab and Nada the Muslim.

For this reason, the Guidelines' suggestion that a woman in Nada's position ought to be depicted as fearing persecution on the basis of religion may be too simplistic, at least to the extent that this may not comport with her claim that it is not Islam per se that is the problem, but rather the "interpretations and discursive uses of Islam" ${ }^{177}$ by the state. In this case, she may see her oppressor as the state, and define the basis of her persecution as a political opinion. On the other hand, if $\mathrm{Nada}$ renounces Islam because she accepts the state's interpretation as accurate, the framing of her claim may well name Islam as the agent of her oppression. This, in turn, raises the question of whether the basis of a given refugee claim ought to "float" in

174. For recent scholarship by Muslim feminists, see Women in the Middle East: Perceptions, Realities and Struggies for Liberation (Haleh Afshar ed., 1993); Leila Ahmed, Women and Gender in Islam (1992); Farida Shaheed, Controlled or Autonomous: Identity and the Experience of the Network, Women Living under Muslim Laws, Signs 997 (Summer 1994).

175. Gayatri Spivak, Acting Bits/Identity Talk, 18 CRITICAL InquIRY 770, 800 (1992). Spivak was speaking in the context of Hinduism, but the same could be said of Islam or any other enforced orthodoxy.

176. For example, I may be privileged as a white person, disadvantaged as a woman, comfortably located in my middle class status, and somewhere in the middle of a complicated ethno-religious hierarchy as a Jew. Where I am situated in any given moment may vary with the particular context in which I am operating and the criteria against which 1 am being scrutinized.

177. Annie Bunting, Theorizing Women's Cultural Diversity in Feminist International Human

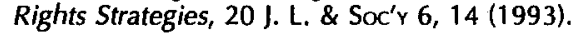


accordance with the claimant's own construction of her experience. ${ }^{178}$ While this approach is certainly compatible with a woman-centered epistemology, integrating it into the "objective" (and objectifying) standards employed in refugee law may prove problematic. Realistically, one is unlikely to observe such nuances emerging in refugee jurisprudence. Its significance may be greatest in the lawyer-client relationship (if the claimant is fortunate enough to be represented), at the point where the two struggle with choices about how to represent the woman's experience into a juridically cognizable form.

\section{B. Reinterpretation Versus Accretion}

As noted earlier, the feature of the Guidelines which has proved most vexing to many commentators, refugee activists, and feminists is their failure to simply add gender (or sex) to the list of grounds of persecution. ${ }^{179}$ Because only the government possesses jurisdiction to amend the refugee definition set out in the Immigration Act, this cannot be held against the IRB, which produced the Guidelines. As it happened, opposition NDP Member of Parliament, Dan Heap, introduced a private members bill on 27 April 1993 to do just that. His proposed amendment would have defined a refugee as one who flees

(a) by reason of a well-founded fear of persecution for reasons of race, sex, religion, nationality, membership in a particular social group or political opinion. ${ }^{180}$

One could envisage the same proposal being made in the international arena with respect to amending the Convention itself, though Hathaway makes the compelling argument that reopening the Convention for revision, at a time of escalating antipathy and xenophobia toward refugees, could prove dangerous and self-defeating.

The claim that reinterpreting the existing refugee definition is inferior to adding gender as a ground of persecution must, in my view, sustain the following two propositions. First, adding gender will protect a greater range

178. As a practical matter, most people making refugee claims in Canada are so bewildered and alienated that they rely heavily on lawyers, who perforce must act as cultural mediators in translating the claimant's story into a cognizable claim that will appeal to the world view of the Board. It would not be surprising if the complexity of the claimant's self-understanding gets lost in the process.

179. See, e.g., Linda Hossie, For Women, Oppression is Often a Way of Life, Globe AND MalL, 5 Feb. 1993, at A15.

180. Bill C-424, 3rd Sess. 34th Parl., 40-41-42 Eliz. II, 1991-92-93. The Bill, like most private members bills by opposition members, did not get past first reading. 
of gender-based claims than utilizing the existing grounds along the lines commended by the Guidelines. Second, the perils of the discursive strategy of reinterpretation are greater than those posed by the explicit addition of gender.

On the first issue, journalist Linda Hossie forcefully advances an argument in favor of altering the definition to explicitly enumerate gender rather than dealing with gender persecution through the existing definition:

The problem with the draft guidelines, meanwhile, is that they treat women's refugee problems as a subtle variation of men's. But the situation of women is unique.

Forced abortion, forced pregnancy, ritual (and disabling) clitoridectomy-all of which are appallingly common-are forms of persecution that have no parallel in men's experience. To oblige women seeking asylum to prove that such treatment is just a variation of the oppression faced by men is illogical andwhen you get right down to it-discriminatory.

Even when women face routine political, religious or ethnic persecution, it is compounded by their almost universal second-class status. Women draw the ire of sexist cultures much more readily than do men, and for much less provocative actions.

The reason that women's groups around the world are fightirg to have sexually based persecution made a legal basis for refugee claims, to have rape declared a war crime and to have women's rights declared human rights, is to focus attention on the systemic, daily, inescapable oppression of women's normal lives in most countries....

There is nothing to stop Canada from broadening its own legal definition to include those suffering sex-based persecution. Nothing but bias. ${ }^{181}$

I believe that Hossie is alerting us to the critical importance of naming what is done to women as "gender persecution" and not masking it with some other label. Not naming it for what it is trivializes gender persecution as less damaging than race or religious persecution, and perpetuates the invisibility of its victims. For instance, the suggestion that $\mathrm{Nada}$ was persecuted simply because she would not accede to the tenets of the dominant view of her religion does seem to occlude the critical dimension of gender as a reason for persecution.

Mattie Stevens also asserts unequivocally that anything short of adding gender to the categories of the refugee definition is inadequate. ${ }^{182}$ Although

181. Hossie, supra note 179.

182. Mattie Stevens, Recognizing Gender-Specific Persecution: A Proposal to Add Gender as a Sixth Refugee Category, 3 Corneu J. L. \& Pus. Poi'r 179 (1993). 
writing in the American context, she does advert to the Guidelines' approach in her analysis, before coming to the following conclusion:

The current categories of the refugee definition do not accommodate genderspecific persecution. Nor does the existing immigration adjudicatory structure see and understand the situation of women. No cohesive framework exists within which to evaluate gender-specific claims. United States law could attempt to incorporate the claims of women into the [Convention] Protocol's categories, but that would not recognize the fact that the type of persecution women face is different from that of men. Nor would it compensate for the decidedly white, male slant of the current definition, or the biases of the immigration judges and the [Bureau of Immigration Appeals]. Thus, legislators must create a separate category. ${ }^{183}$

Despite the vigor of Stevens' rhetoric, she does not provide any scenario of gender persecution that would be rejected under the Guidelines' approach, but would succeed if gender were an enumerated category. Moreover, it is doubtful that the biases Stevens attributes to refugee decisionmakers could be transformed by the addition of a single word to the refugee definition. If the decisionmakers are as resistant as she suggests, they could probably subvert any language one might insert into the definition. If it follows from this that adding gender is not sufficient in the absence of competent and sensitive decisionmakers, one might query whether it is even necessary if decisionmakers possess the will and ability to interpret the existing definition in a gender-sensitive manner.

A more serious defect in Stevens' and Hossie's proposals to add gender as a ground of persecution subsists in their tacit assumption that every case of gender persecution is persecution because of gender. Were this proposition true, then no case of gender persecution could be properly addressed without adding gender (or sex) as a sixth category of persecution, and doing so would resolve every situation in which gender is relevant. In my view, however, it is a mistake to equate "gender persecution" with "persecution on grounds of gender," or "persecution because of gender."

"Gender persecution" includes, but is not limited to, "persecution because of gender." Certainly, gender may explain why a woman was persecuted. Gender may also determine the form that persecution takes. Sometimes, it may even be a risk factor that makes a woman's fear of persecution more well-founded than that of a man in similar circumstances. $^{184}$ Though one or more of these links between gender and

183. Id. at 214-15.

184. In China, parents who have more than one child face the risk of forced sterilization. Women are more likely than men to be forcibly sterilized, though a husband may be 
persecution may be present simultaneously in a given case, they are not synonymous. The idea of women being persecuted as women is not the same as women being persecuted because they are women. The former addresses forms of persecution that are gender-specific. Understanding the ways in which women are violated as women is critical to naming as persecution things that are done only or mostly to women and not to men. To say that the claimant fears persecution because she is a woman addresses a causal relation between gender and persecution.

For example, one may be persecuted as a woman (e.g., raped) for reasons unrelated to gender (e.g., membership in an opposition political party), not persecuted as a woman but still because of gender (e.g., flogged for refusing to wear a veil), ${ }^{185}$ and persecuted as and because one is a woman (e.g., genital mutilation). All three of these cases present examples of gender persecution, but it does not follow that each of them ought to be framed as persecution on grounds of gender, whether gender is propounded as a separate ground of persecution or as a particular social group. In particular, it is more apt to describe the first claimant as one who fears persecution on the basis of a political opinion, not gender. Recognizing rape as a type of torture permits the conclusion that what was done to the claimant was indeed persecution.

Why insist on these apparently semantic distinctions? First, it is important to be clear on the relationship between gender and the elements of the refugee definition. If a man's testicles are subjected to electric shocks, the victim is certainly being tortured in a gender-specific way, but it does not follow that he is being persecuted on grounds of gender. Gender-related violations do not necessarily constitute persecution because of gender.

Second, it is important to avoid the twin extremes of collapsing every persecution of women into the category of "persecution on grounds of gender," versus submerging the gender component entirely under other labels. The trouble with framing any persecution of women as "persecution because of gender" is that it can reinforce women's marginalization by implying that only men have political opinions, only men are activated by religion, only men have racial presence, etc. In other words, it may create

vulnerable if his wife is unable to undergo the procedure. Thus, parents with more than one child may both fear forced sterilization, but the mother's fear might be more "well founded" than the father's. In this way, gender informs the assessment of whether the fear is "well-founded." This possibility was not considered in either Cheung, supra note 68, or Chan, supra note 69.

185. Another illustration would be wife battering. I anticipate that some would consider the battered woman to be persecuted as a woman in the sense that domestic violence is virtually always inflicted by a man on a woman. In my opinion, however, there is nothing inherently gender-specific about being beat up. 
and sustain the stereotype that men "own" the categories of oppression that are not explicitly "gendrified." On the other hand, the trouble with not acknowledging gender as a discrete basis of persecution is that it masks the specificity of women's oppression. The formal distinctions drawn here are intended to mediate between these two poles, in the hopes of minimizing the dangers attendant upon a wholesale application of either one. For their part, the Guidelines provide illustrations of the manifold ways in which gender affect both the form of and reasons for persecution, but the Guidelines do not attend to the distinction in the analytical framework suggested for assessing gender-based claims.

While I share a sense of dissatisfaction about the Guidelines' tacit suggestion to employ religion, race, or nationality as devices to avoid dealing expressly with gender, there is a strong argument that 'political opinion' may well include women's opposition to extreme, institutionalized discrimination. Political opinion as a ground of persecution does not suffer from the same partiality as do religion or race. That is, it does not address only a single aspect of persecution experienced by the woman claimant. Instead, it equates resistance to gender oppression with a political opinion, thus seizing the language of liberal democratic rights discourse and refashioning it for feminist use. The same defect of masking gender under another name can be made against it, however. At the same time, identifying women's resistance to gender subordination as political opinion strikes me as profoundly feminist, if indeed one believes that "the personal is political," and that patriarchy is a system constituted primarily through power relations, not biology. So in the end, using the category of "political opinion" may not be objectionable at all.

The most dramatic use of "political opinion" in a gender based claim appears in the US case Olympia Lazo-Majano v. Immigration and Naturalization Service. ${ }^{186}$ In its judgment, the Ninth Circuit Court of Appeals considered the claim of a Salvadoran domestic worker who was repeatedly raped by her employer, a sergeant in the Salvadoran military. Her abuser threatened to torture her in other ways, kill her children, and "denounce" her as a subversive if she resisted. The abuser was acting outside of his official duties. ${ }^{187}$ On an appeal from her rejection before the Board of Immigration Appeals, the Ninth Circuit characterized the reason for the claimant's persecution as follows:

186. 813 F.2d 1432 (9th Cir. 1987).

187. For further discussion of this case and of sexual assault as persecution generally, see Castel, supra note 59. 
[1] $f$ the situation is seen in its social context, Zuniga is asserting the political opinion that a man has a right to dominate and he has persecuted Olympia through force to accept this opinion without rebellion. Zuniga told Olympia that in this treatment of her he was seeking revenge. But Olympia knew of no injury she had ever done Zuniga. His statement reflects a much more generalized animosity to the opposite sex, an assertion of a political aspiration and desire to suppress opposition to it. Olympia was not permitted by Zuniga to hold an opinion to the contrary. When she asserted one, she became exposed to persecution for her assertion. Persecution threatened her because of her political opinion. ${ }^{188}$

The dictum is exceptional in two senses of the word-it is a radically feminist pronouncement by a US court, and it has never been followed in any other reported case. What this suggests is that pushing "political opinion" to its logical limit should not be discounted, but tactically it may not be the most viable route.

As with "political opinion," including women under the rubric "particular social group" also works, subject to the concerns expressed above about how the group ought to be defined.

Calling women a particular social group can be useful in focusing attention on the extent to which the apparently natural category of "woman" is socially constructed. Even if one can provisionally accept that the universal consequence of being labelled "woman" is subordination, the particular form it takes varies culturally, geographically, and temporally. Application of a gender-sensitive interpretation of "persecution" assists in delineating the specificity of women's oppression, while employing the social group label "women" reminds us of the common social position of women all over the world.

Though formulating a particular social group called "women" effectively meets the main practical objectives of designating gender as a separate ground of persecution, a concern is raised by this "particular social group" strategy in that gender is being relegated to some marginal subcategory. Surely persecution on the basis of gender is at least as prevalent, as pernicious, and as worthy of formal recognition as persecution on the basis of race, religion, nationality, etc. My rejoinder is that race, religion, and nationality are no less socially constructed than gender. It seems trite to observe that differences in skin colour, faith, and national origin only become "reasons" for persecution through the inscription of social meanings upon those characteristics by those with the power to generate

188. Lazo-Majano, supra note 186 , at 1435. 
hierarchy out of difference. Indeed, given a choice, I would advocate collapsing race, nationality and religion into the "social group" designation as well. ${ }^{189}$ One cannot deny the possibility that the existence of certain 'named' categories may appear to give women qua social group a lesser status. At this stage, one must consider whether the appropriate tactic is to enhance the position of women within a flawed structure, or to adopt a principled position at the expense of giving gender the status of a discrete ground of persecution.

At least one more factor ought to be figured into the calculus. Interpreting the existing Convention refugee definition to include women as a particular social group sets a salutary precedent in two ways. First, other nations that are states parties to the Convention can look to the Canadian approach in applying the Convention definition in their own jurisdictions. If Canada added gender as a separate category, decisionmakers elsewhere could easily dismiss the relevance of Canadian caselaw on gender-related claims on the basis that the refugee definition in Canada is different.

Second, women are not the only vulnerable group who are unnamed in the refugee definition. Disabled people, the very young and the very old, and lesbians and gays may all experience oppression because of their personal characteristics. At various times and in various locations, the treatment that they endure doubtless constitutes persecution. If women are understood as comprising a particular social group, a precedent is established for interpreting the particular social group category in the Convention refugee definition in ways that encompass age, sexual orientation, ${ }^{190}$ disability, etc. If gender is added as a separate category, decisionmakers would have an excuse for rejecting claims based on these other grounds. They could simply assert that if the drafters had intended to include disability (or age, etc.) in the refugee definition, they would have said so explicitly, as they did with gender. ${ }^{191}$ In short, it is appropriate to attach value to a strategy that has the potential of opening the door to recognizing other bases of persecution, thus forging solidarity across categories of oppression.

189. This would leave only two categories upon which a claim of persecution would be based-particular social group (who you are) and political opinion (what you believe). Of course, a despised group may be assumed by the state to hold political opinions that are inimical to the extant distribution of power (e.g. South African blacks may be presumed to be anti-apartheid). In the end, even the distinction between political opinion and social group may become artificial.

190. As noted earlier, Ward indicates that sexual orientation could be the basis of social group ascription. See also CRDD No. T91-04459, Teitelbaum, Colle (diss.) 12 Mar. 1993 (Argentinian man's fear of persecution because of sexual orientation accepted).

191. In fact, prior to the Guidelines, this is exactly what one panel did. In rejecting the claim of an Ecuadoran claimant fleeing an abusive partner, the panel conceded that she had 
Whether gender is enumerated explicitly or through the "particular social group" designation, it is important to recognize that refugee law, unlike Canadian and US equality jurisprudence, has no difficulty contemplating the possible multiplicity of grounds of persecution. The UNHCR Handbook clearly states:

It is immaterial whether the persecution arises from any single one of these reasons or from a combination of two or more of them. Often the applicant himself [sic] may not be aware of the reasons for the persecution feared. It is not, however, his duty to analyze his case to such an extent as to identify the reasons in detail. ${ }^{192}$

Thus, despite the tendency in the Guidelines to promote use of the enumerated grounds of persecution before turning to a gendered version of "particular social group," there is no legal motive for choosing between grounds, if more than one is apposite. If, as the Guidelines observe, both race and sex may explain why an Asian woman has a well-founded fear of persecution in Africa, both can be asserted jointly as the grounds of persecution. This easy acceptance of "intersectionality" in refugee law minimizes the danger of distorting the presentation of a woman's claim in the name of facilitating success in the hearing room.

\section{Clash of the Discourses}

Beginning with Simone de Beauvoir and moving on to contemporary postmodernists, feminist theorists both delineate and critique a model of Woman as objectified Other, against whom Man defines and asserts himself as subjective Self. ${ }^{193}$ Parallel dichotomies have been drawn along the dimensions of race and culture: the westernized or northern Self versus the exotic eastern or southern Other. As in these domains, so too can refugee discourse be organized according to a Self/Other opposition. In the refugee context, there are "refugee-producers" and "refugee-acceptors." Canada,

been persecuted and that the state could not protect her. Nevertheless, it ruled that her fear of persecution was not related to any of the Convention grounds.

One's sex is not one of the five enumerated reasons. It was within the power of the drafters of the Convention to include sex as an independent reason, and they apparently chose not to do so. It was also within the power of Parliament to include sex as an independent reason, when incorporating the Convention definition as part of our Act, and they also apparently chose not to do so. Such being the case, it would appear that a claim based solely on the sex of a claimant does not fall within the parameters of the definition.

CRDD No. T92-03227, supra note 141 , at 8.

192. UNHCR Handbook, supra note 36, at I 66.

193. For an introductory survey of various conceptions of woman as Other, see ROSEMARIE Tong, Feminist Thought 195-234 (1989). This binary structure of analysis is not universally accepted by feminists, nor does consensus exist regarding the signification and valuation of being Other. 
the United States, Australia, New Zealand, and the states of Western Europe (that is to say, the "Western" nations) locate themselves firmly in the latter camp, and constitute themselves as distinctive and superior by reference to what they are not, namely, the kind of governments that do the kinds of things to people that propel them to claim refugee status. To describe oneself as a refugee-acceptor is to say that one is also a "nonrefugeeproducer." Indeed, during the Reagan/Bush era, the United States projected this formulation even further. Because the United States does not produce refugees (so the argument went), it followed that it could not participate in generating refugees elsewhere. ${ }^{194}$ Therefore, no government supported by the United States (Guatemala, El Salvador, etc.) could possibly be a refugeeproducing country. In reality, the categories are not always mutually exclusive; the Ward case features a refugee claimant from Ireland. Yet so strong is the notion that only "they" produce refugees that the most recent amendments to Canada's immigration law raise the standard of proof that claimants from designated "nonrefugee-producing" countries must satisfy to establish their claim. ${ }^{195}$

Now, this distinction between refugee-producing and refugee-accepting countries may have a certain real world appeal when applied to extreme violations of classic liberal individual rights by state agents-the torture of political dissidents, for example. What happens, however, when the Self/ Other bifurcation of feminist discourse is superimposed on this Self/Other dichotomy of refugee discourse? My hypothesis is that taking gender persecution seriously requires one to traverse the boundaries of the binary opposition upon which the refugee paradigm is constructed. In other words, the phenomenon of gender persecution challenges the self-understanding of so-called "nonrefugee-producers."

Consider first the assertion that "severe discrimination on grounds of gender" constitutes persecution. The 1993 UN Human Development Report arrives at the utterly unstartling conclusion from its analysis of 33 countries,

194. See National Asylum Studo Project, An Interim Assessment of the Asylum Process of the Immigration and Naturalization Service (Cambridge: Harvard Law School, 1992), at 1. (As of 1988, "Applicants from countries considered "hostile" to the United States, such as the former Soviet Union, the People's Republic of China and Iran, were granted at a rate greater than 50 percent. By comparison, applicants from countries considered "friendly" to the United States, such as Guatemala and El Salvador, were granted at a rate less than 3 percent, regardless of the strength of the case.")

195. Refugee claims are adjudicated in panels of two. In the event of a tie, the decision goes in favor of the claimant unless the claimant, inter alia, comes from a country designated by regulation as "a country that respects human rights." Immigration Act, $\$ 69.10$. The legislation was enacted early in 1993, and the Conservative government that passed it did not designate any countries prior to being voted out of office. The new Liberal government has not designated any countries. 
that "no country treats its women as well as it treats its men." ${ }^{196}$ Japan ranks among the worst of those who record gender-based statistics, but both Canada and the United States fell in their quality-of-life rankings when the treatment of women was included. ${ }^{197}$

Given that every country discriminates against women, how will the line be drawn between "mere" discrimination, and discrimination so "severe" that it amounts to persecution? One concern is that the line may be drawn by reference to whatever "we" (the nonrefugee-producing country) do. What "we" do is discrimination. The more the claimant's state looks different from ours, the more what "they" do begins to look to "us" like persecution. In other words, the fear is that cultural difference may become the yardstick along which the shift from discrimination to persecution will be measured.

The same principle may apply to the assessment of whether the state is able or willing to protect a claimant from private acts of violence. Indeed, the Ward decision hints at this propensity by citing with approval the Federal Court of Appeal judgment in Satiacum v. MEI. ${ }^{198}$ The case involved a US Indian Chief who was convicted of federal criminal charges but fled to Canada before sentencing. He based his refugee claim on the contention that his life would be endangered if he were incarcerated in a federal prison and that the US authorities would be unable to protect him from that risk. Although his claim succeeded before the Immigration Appeal Board, ${ }^{199}$ on review, the Federal Court of Appeal rejected Satiacum's fear as "well founded" by invoking a presumption that democracies (like the United States) have fair and independent judicial processes. This presumption can only be rebutted by evidence "substantially impeaching, for example, the jury selection process in the relevant part of the country, or the independence or fair-mindedness of the judiciary itself." ${ }^{200}$

Justice La Forest endorsed this heightened presumption against the legitimacy of claims from democratic countries as follows:

Although this presumption increases the burden on the claimant, it does not render illusory Canada's provision of a haven for refugees. The presumption serves to reinforce the underlying rationale of international protection as a surrogate, coming into play where no alternative remains to the claimant.

196. United Nations Development Procramme (UNDP), Human Development Report 199316 (1993).

197. Id. Sweden, Denmark, and New Zealand improved their rank when gender was taken into account, suggesting that the gender "gap" in quality of life is smaller in those countries.

198. 99 N.R. 171 (1989).

199. The predecessor to the Immigration and Refugee Board.

200. Satiacum, supra note 198, at 176 (quoted in Ward, supra note 11, at 725 ). 
Refugee claims were never meant to allow a claimant to seek out better protection than that from which he or she benefits already. ${ }^{201}$

Implicit in this passage is the assumption that unless and until the claimant can impeach the integrity of the entire criminal justice system in all its manifestations, recourse to local protection remains a meaningful alternative to flight. Quite apart from the dubiety of this presumption, the evidentiary hurdle placed before the claimant is practically insurmountable, and virtually guarantees that she will be unable to rebut the presumption that local protection is a genuine option. Consider the US woman who is battered by her spouse. It is well known that the "system"-from police, to prosecutors, to judges, fails to protect women from abusive partners. ${ }^{202}$ While a woman may be able to describe incidents from her own experience that illustrate this phenomenon, how can she bring the entire US police and judicial machinery into disrepute? Does it matter if five women were protected from their abusers if fifty others (including her) were not, or vice versa? The availability of state protection can rarely be described in absolutes. How often does it have to fail before a claimant's fear of abuse and lack of faith in state protection will be validated as objectively wellfounded? ${ }^{203}$

The near impossibility of displacing a presumption in favor of democracies like Canada serves another important legitimating function. If the United States were ever understood to be a producer of refugee women, could Canada escape the same verdict? If the Canadian state cannot, or will not, protect its own women nationals any better than does the United States, any Canadian tribunal that grants asylum to a US woman fleeing domestic violence veers perilously close to confronting the fact that the same country that has won deserved praise for enacting the Guidelines is also implicated in practices that amount to gender persecution. Erecting an evidentiary barrier to the admission of refugee claimants from countries [un] comfortably similar to Canada presents one strategy for deflecting this discomfiting irony. It does so only at the expense of diluting persecution from an absolute to a relative condition. One is persecuted if the state cannot, or will not, protect you, but only if Canada can or will protect you in similar circumstances.

The perils of pursuing a gender analysis to its logical conclusion are glaring. At some point, every country becomes a refugee producing country. The reason no one notices is because women have nowhere to flee. There is no safe haven: "As a woman I have no country."

201. Ward, supra note 11 , at 726 .

202. See Statistics Canada, The Violence Against Women Survey, THE DAlLY, 18 Nov. 1993.

203. In the unlikely event that an American woman ever made a claim of this type in Canada, it would likely founder on the availability of an internal flight alternative. 
Once again, I worry that cultural chauvinism may be employed to distinguish between those states which are "unwilling or unable" to protect women from domestic violence (non-democracies, current refugee producers), and those states whose justice systems are simply "imperfect" and cannot be held accountable for an inability to protect each individual woman from each individual criminal assailant (democracies and general respecters of human rights). Indeed, recent feminist scholarship from the United States on gender persecution and refugee status evinces a distressing degree of cultural hyperopia regarding local conditions for women. It seems that when some North American feminists want to make a pitch for granting asylum to victims of gender persecution elsewhere, they become tactically blind to the compelling evidence gathered by other North American feminists documenting local practices that might constitute gender persecution. At the very moment North American feminists turn to condemn misogyny in the "third world," they lose sight of the fact that our own culture hardly presents a model of gender equality.

For example, Linda Cipriani ${ }^{204}$ surveys the world, gathering examples of gender persecution. She takes her samples from Iran and Pakistan (Islamic Law), India (Hinduism), Africa ("tribal custom"), Brazil, Argentina, and Peru ("machismo policies and practices"). ${ }^{205}$ In each case, the source of persecution is located in a religion other than Christianity, customs of nonwhite societies, or "cultural norms" about women that are portrayed as locally specific. For instance, Cipriani attributes the patriarchal orientation of law in South America to the stereotypes of machismo and marianismo, with no mention of the influence of the Catholic church in sustaining and perpetuating misogynist practices. Conversely, Hinduism and Islam are identified as the culprits in the persecution of women in Iran, Pakistan, and India.

According to the data collected by Cipriani about Zimbabwe, "wife beating is a 'major problem' and the police rarely interfere. ${ }^{\text {"206 }}$ In Peru, "eighty percent of all violent crimes reported to the police on a daily basis are beatings of women by their husbands. Police give these crimes low priority. ${ }^{\prime 207}$ One might assume from her depiction that what goes on in Zimbabwe and Peru is exceptional; yet, anyone acquainted with violence against women in North America knows otherwise. The inadequacy of the official response to domestic violence characterizes every country, including the United States and Canada. In fact, most of the available data on

204. Linda Cipriani, "Gender and Persecution" Protecting Women Under International Law, 7 Geo. IMM. L.J. 511 (1993).

205. Id. at 513-33.

206. Id. at 524-25.

207. Id. at 531 . 
domestic violence emerges from studies conducted in North America, Western Europe, and Australia/New Zealand. ${ }^{208}$

In addition, North American feminist scholars themselves have zealously exposed the practice of domestic violence in the United States (and elsewhere) as a potential international human rights violation. In her article, Recognizing the Egregious in the Everyday: Domestic Violence as Torture, Rhonda Copelon explains her decision to use domestic violence as the focus of her inquiry as follows:

I have deliberately chosen to focus on the most mundane and universal form of violence, and one which is equally prevalent in United States society, rather than on forms of violence that are viewed as unusual by Western societies. I do this ... because pointing the finger at other culture-specific forms of gender violence such as genital mutilation or dowry deaths undermines taking seriously comparable wrongs in this society; ... ${ }^{209}$

In a similar vein, Katherine Culliton ${ }^{210}$ details the extent of domestic violence in the United States, Brazil, and Chile in order to vindicate "American women's fundamental right to state protection from domestic

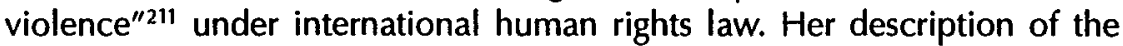
condition of women in the Americas reveals that, if differences exist in the adequacy of state protection, such differences are quantitative and not qualitative. In her view, all surveyed states in the Americas fall below acceptable standards. Neither Copelon nor Culliton direct their attention to the refugee context. Yet, it is virtually axiomatic to state that, if domestic violence is torture, and the United States does not respect a woman's right to state protection from domestic violence qua torture, at least some US women would be viable candidates for refugee status.

One group of women who are particularly vulnerable to domestic violence in North America are migrant women. Ironically, Pamela Goldberg commences her article advocating asylum for women fleeing intimate violence with the story of an undocumented Pakistani woman living in the United States with her abusive husband, who was a legal resident. ${ }^{212}$ Goldberg's narrative depicts how the woman fears leaving her husband and returning to Pakistan, because either his or her family will "punish" her for

208. Violence Against Women in the Family, supra note 143, at 5.

209. Rhonda Copelon, Recognizing the Egregious in the Everyday: Domestic Violence as Torture, 25 Col. Hum. Ris. L. Rev. 291, 296 n.12 (citations omitted) (1994). Her article is in many ways a companion piece to Romany's stimulating article, supra note 103.

210. Katherine Culliton, Finding a Mechanism to Enforce Women's Right to State Protection from Domestic Violence in the Americas, 34 HARV. INT'L L.J. 507 (1993).

211. Id. at 507.

212. Goldberg, supra note 13 , at 567. 
"disrespecting her husband." She "also believes that the police and the courts [in Pakistan] would do nothing to protect her-nor would they be able to-because the family is considered sacrosanct and the law will not act in any way to interfere in such matters. ${ }^{\prime 213}$ Curiously, the fact that the husband beat, slapped, punched, and verbally abused his wife with impunity for several years in the United States escapes comment. ${ }^{214}$ Elsewhere, American Margaret $\mathrm{O}^{\prime}$ Herron ${ }^{215}$ cogently demonstrates how the US Marriage Fraud Act ${ }^{216}$ actually heightens the vulnerability of immigrant women who are dependent on their spouses to sponsor them for permanent residence. The statute requires that nonimmigrant spouses be sponsored by citizens or permanent residents. Women in battering relationships will not report abuse to the police for fear that their spouses will disclose their undocumented status or withdraw extant sponsorship applications, either of which could lead to deportation. As O'Herron states, the Marriage Fraud Act "cruelly forces many immigrant women to choose between risking their lives as victims of battery and risking their lives as deportees to countries in which survival may be unlikely." 217 In this sense, US law (and its Canadian counterpart) ${ }^{218}$ effectively denies protection to immigrant women who are battered. However, Goldberg's narrative suppresses this reality in order to play up the brutality facing the claimant in Pakistan.

Perhaps the most striking illustration of how Western advocates don blinders for tactical reasons occurs in the context of sexual orientation as a basis for asylum. In her article, "Give Me Liberty or Give Me Death: Political Asylum and the Global Persecution of Lesbians and Gay Men," Suzanne Goldberg ${ }^{219}$ urges refugee recognition for lesbians and gays who are persecuted because of their sexual orientation. Ms. Goldberg acknowledges that several US states criminalize consensual sex between lesbians

213. Id. at 568 .

214. In the author's narrative, the woman sought refuge in a woman's shelter. No reference to police or state protection is made.

215. Margaret M.R. O'Herron, Note, Ending Abuse of the Marriage Fraud Act, 7 Geo. Immicr. L.J. 549 (1993).

216. Immigration and Nationality Act, 8 USC $\$ 1186$ a (1986).

217. O'Herron, supra note 215 , at 567 .

218. In a case reported in the Canadian press, Judy Henderson's husband withdrew his sponsorship after she had him charged with assault. Henderson, who was pregnant, faced the prospect of deportation to Trinidad a week before the assault trial. Immigration-Abuse, Bgt, CANAdian Press, 29 Dec. 1993, available in QUICKLAW, CP93 Database. More recently, Marie Sanchez, a Nicaraguan immigrant, was deported when her abusive husband withdrew her sponsorship after she left him. The Department of Citizenship and Immigration has since formed a team to investigate the withdrawal of sponsorships of immigrant family members. Abuse of Sponsored Women Probed, GLOBE and Mall, 22 July 1994, at A4.

219. Suzanne Goldberg, Give Me Liberty or Give Me Death: Political Asylum and the Global Persecution of Lesbians and Gay Men, 26 CORNeLL INT'L L.J. 605 (1993). 
and between gay men, and that these laws have been upheld as constitutional by the United States Supreme Court. ${ }^{220}$ Ms. Goldberg ducks this embarrassing conundrum by implying that laws criminalizing consensual sex between same-sex partners only amount to persecution "when the penalties imposed are extremely severe, disproportionate to the putative statutory goal, or administered without due process." ${ }^{221}$ Goldberg appears to accept that criminalization itself would be insufficient to constitute persecution. Goldberg continues in the same vein by contending that, in any event, "criminalization of sodomy in parts of the United States should not interfere with the grant of asylum to a person whose life is endangered because she or he is lesbian or gay":222

The Supreme Court's ruling in Bowers v. Hardwick that the constitutional right to privacy does not encompass sexual relations between consenting lesbian and gay adults is largely irrelevant to the discussion of whether lesbians and gay men are eligible for asylum. Bowers, a due process challenge to the Georgia sodomy law, focuses exclusively on criminalization of sexual conduct, with no reference to lesbian or gay identity. Moreover, both before and after Bowers, courts have refused to permit infringement of established constitutional guarantees of equal protection and first amendment freedoms based on prejudice against gay men and lesbians. ${ }^{223}$

Goldberg's attempts to find a legal space for refugee status on the basis of sexual orientation while leaving Bowers v. Hardwick undisturbed are lame at best. Her apparent concession that criminalizing sexual relations between consenting adults of the same sex would be insufficient to constitute persecution is inexplicable as a matter of refugee law, because the UNHCR Handbook recognizes that "penal prosecution for a reason mentioned in the definition . . . may in itself amount to persecution." ${ }^{\prime 224}$ To the extent that sexual orientation may constitute membership in a particular social group (as Justice La Forest stated in Ward) it is certainly arguable that the criminalization of sexual relations among lesbians and gay men per se constitutes persecution. Moreover, her overdetermined distinction between lesbian and gay identity versus lesbian and gay sexual activity, is a product of necessity arising from trends in US jurisprudence. Apart from that context, the claim that there is "a critical distinction between regulation of sexual activity and persecution of lesbians and gay men"225 is a distinction

220. Bowers v. Hardwick, 478 U.S. 186 (1986).

221. Id. at 620-21.

222. Id. at 621 .

223. Id.

224. UNHCR Handbook, supra note 36 , at $\eta 85$.

225. Id. 
without a difference when it comes to consensual sex between adults of the same sex. How much simpler it would be for Goldberg to just admit that certain states in the United States persecute people within the meaning of the Convention refugee definition on the basis of their sexual orientation! ${ }^{226}$

There are two plausible explanations for the unwillingness of Western scholars to own up to their own countries' persecutory practices, be it with respect to violence against women, or the persecution of lesbians and gay men. One reason is the implicit binary structure of refugee discourse. If the United States, or Canada, or Australia are refugee-acceptors, it follows that whatever they do cannot constitute persecution, because that would make them potential refugee-producers. Even for sincere feminist and lesbian/gay advocates, this unarticulated commitment to the moral status of Western nations qua refugee-acceptors seems to have the effect of temporarily disconnecting the local outlet of an otherwise lively critical apparatus. It is one thing to admit to ourselves that our local practices violate fundamental human rights; it is quite another to admit it to the international community.

There is another related reason why commentators may deliberately ignore or repress reference to local practice. In principle, refugee status is an absolute concept. If one is persecuted, one is entitled to asylum. Yet, if countries of refuge cannot guarantee a woman that she will be protected from the kind of persecution that she flees, what is the point of granting her refuge? Indeed, can one even talk meaningfully about "refuge" under these circumstances? The problem is particularly acute for feminist theorists. Women's exclusion from a given patriarchal civil society is often depicted in the scholarship as the denial of citizenship status. ${ }^{227}$ Or, as Celina Romany asserts, "Women are the paradigmatic alien subjects of international law ... Women are aliens within their states, aliens within an international exclusive club that constitutes international society." ${ }^{228}$

Although it may be tempting to claim that women are not true citizens in any society, this assertion proves too powerful when held up against the claims of women who are literally and physically exiled from their countries of nationality. Thus, the danger of confronting the universality of women's oppression lies in the rejoinder that women are always and never refugees-always, because they cannot confidently rely on state protection wherever they live; and never, because there is no place to which they can

226. Much like US women who are battered, Georgian gays and lesbians would probably fail in any putative refugee claim because they have an "internal flight alternative." They can move to a state that does not criminalize homosexuality. This does not detract from the persecutory character of the laws, however.

227. See Susan Moller Okin, Women in Western Poltical Thought (revised ed. 1992); Elshtain, supra note 101; Pateman, supra note 101.

228. Romany, supra note 103, at 85. 
flee. For those who champion the claims of women fleeing gender persecution, this latter inference must be avoided at all costs. One tactic is to ignore or downplay the pervasive failure of refugee accepting countries to protect women from intimate violence.

The practical consequence of this effacement will be that gender persecution will be most visible and identifiable as such when it is committed by a cultural Other. This strategy will enable so-called refugeeacceptors to neutralize and assimilate feminist insights about the relationship between patriarchy and the state into a refugee determination system that desires, above all, to sustain its self-understanding as a nonrefugeeproducer. Practices such as dowry burning, dress codes, and genital mutilation will present cases that are relatively "easy" to recognize as gender persecution. State indifference to violence against women will be more problematic, and the identity of the country of nationality as a traditional "refugee-producer" may well enhance the probability of success for the claimant.

At one level, this provisional stance of Western superiority in the realm of gender relations seems innocuous enough, in that it is deployed in a discursive setting that is meant to benefit individual women seeking asylum. At another level, however, it bespeaks a certain ethnocentrism that is willing to posit Western women as "the normative referent" 229 against which the situation of Other women will be evaluated-and pitied. In her critique of the portrayal of the "third world woman" by some feminist scholars, Chandra Mohanty reveals the patronizing implications of this method:

a comparison between Western feminist self-presentation and Western feminist re-presentation of women in the third world yields significant results. Universal images of the "third world woman" (the veiled woman, chaste virgin etc.), images constructed from adding the "third world difference" to "sexual difference," are predicated upon (and hence obviously bring into sharper focus) assumptions about Western women as secular, liberated, and having control over their own lives. This is not to suggest that Western women are secular, liberated and in control of their own lives. I am referring to a discursive selfpresentation, not necessarily to material reality. If this were a material reality, there would be no need for political movements in the West. ${ }^{230}$

Far from complaining that Western feminists are indulging in essentialism by projecting their own experiences as universal, Mohanty reproaches them for going to the opposite extreme. This is what philosopher Jane

229. Chandra Mohanty, Under Western Eyes: Feminist Scholarship and Colonial Discourses, in Thiro Worlo Women and the Politics of feminism 51, 56 (Chandra Mohanty et al. eds., 1991).

230. Id. at 74 . 
Roland Martin ${ }^{231}$ calls the "self-made trap of false difference." 232 Martin asserts that in the rush to atone for the sins of essentialism, some feminists have fetishized differences among women to the point where there exists nothing except difference: ${ }^{233}$

Cutting us off from the developmental insights of feminist psychologists and denying us the chance to discover even limited cross-cultural and temporal commonalities, [false difference] encourages us to construct not just other times and places but also other women as utterly Other. ${ }^{234}$

What this means in the refugee context is that we suppress the commonality of gender oppression across cultures to ensure that what is done to Other women looks so utterly different from (or unspeakably worse than) what is done to women here, that no one would notice a contradiction in admitting them as refugees. The logic of the dichotomy of refugeeacceptor/refugee-producer compels a parallel classification of Western woman/Other woman that serves to facilitate the admission of at least some women fleeing gender persecution, but only by adopting a method that is politically and empirically problematic.

If one abandons the provisional fiction that Canada is a haven from gender persecution, does it follow ineluctably that claimants fleeing gender persecution must be rejected? Not necessarily. It would, however, call for a rethinking of the basis upon which refugees are accepted. Asylum is ordinarily predicated on the understanding that one flees a place of danger for a place of safety. Taking seriously the situation of battered women in "refugee-acceptor" states means that granting asylum to battered women from elsewhere offers contingent protection at best. It only protects a particular woman from a particular abuser located in another country, and even then, only if he does not pursue her to Canada. It cannot guarantee her adequate protection should the woman find herself in a battering relationship in Canada.

Dularie's situation provides a useful illustration of this point. The fact that her spouse was convicted eleven times of threatening or committing assaults against her in Canada suggests that the Canadian state did not actually protect her all that effectively from spousal violence, even though prosecution of her husband was more than she ever obtained in Trinidad. At the same time, once her spouse returned to Trinidad (from whence he continued to issue death threats), allowing Dularie to remain in Canada

231. Jane Roland Martin, Methodological Essentialism, False Difference, and Other Dangerous Traps, 19 SiCNs 630 (1994).

232. Id. at 646 .

233. Id.

234. Id. 
furnished her with greater protection than would be available to her in Trinidad. The real test of Canadian commitment to protection may arise if Dularie's husband ever attempts to reenter Canada. Recognizing its sovereign duty to protect nationals, would Canada exclude him at the border in the name of protecting her?

\section{CONCLUSION}

\section{Catharine MacKinnon notes:}

In the structure of international human rights, based as it is on the interest of states in their sovereignty as such, no state has an incentive to break rank by going after another state for how it treats women-thus setting a standard of human rights treatment for women that no state is prepared to meet within its own borders or is willing to be held to internationally.... There is no state we can point to and say, "This state effectively guarantees women's human rights. There we are free and equal. ${ }^{\text {"235 }}$

Though Mackinnon may be right about the self-interest of states in the sphere of international human rights, the Guidelines belie her assertion in the context of refugee law, inasmuch as Canada now presumes to judge how other states treat their women for purposes of refugee determination. By the same token, Canada is still not a country that can proclaim itself a paragon of freedom and sex equality. This paradox is unlikely to vanish in the near future.

It is interesting to speculate about why refugee law seems more amenable than the international human rights regime to acting on the insight that states are as accountable for a failure to protect women from "private" violations as they are for the "public" violations that states themselves commit. Perhaps it is because states owe no obligations to nationals of other countries under international human rights law. There is no incentive to take an active interest in the human rights of women elsewhere, and as MacKinnon points out, a certain self-interest in not doing so. In the refugee context, states party to the Convention are obliged to assess the conduct of other states in the course of resolving individual cases brought before their tribunals. Moreover, a state hearing a refugee claim is bound under international refugee law not to return a claimant to a country where she may be persecuted. In effect, states owe the claimant a legal obligation to judge the actions of the state from which she has fled.

235. Mackinnon, supra note 54 , at 15 . 
By the first anniversary of the Guidelines' release, some 350 genderrelated claims had been identified. Of the 150 claims that were finalized, approximately 70 percent led to the granting of refugee status. ${ }^{236}$ Clearly, decisionmakers are paying attention to the Guidelines. Though members of the CRDD are encouraged to write reasons for positive decisions that apply the Guidelines, and are required to issue written reasons for all negative decisions, relatively few of the decisions have been reported. Therefore, it is not possible to paint a complete picture of who is accepted, from which countries, and for what reasons.

The first case heard after the Guidelines were issued led to a positive determination on behalf an Ecuadoran woman fleeing domestic abuse. The claimant's evidence of her personal experiences and the documentary evidence describing the absence of state protection were so compelling that the Board commented as follows:

This documentary evidence makes it abundantly clear that the government of Ecuador is unwilling to protect the rights of women who are subject to domestic abuse. They have to endure the trauma of violence in silence while the enforcing authority of the state does nothing in their defence, and regards such abuses as domestic issues. This culture of tolerance has been built up over the years and forms part of the ethic of Ecuadorian society. The question is whether the violence endured by these women in appropriate cases should be regarded as persecution. There is a vast difference between a matrimonial home and a torture chamber. If a wife is subjected to violence repeatedly then in our assessment, she stands in no different situation than a person who has been arrested, detained and beaten on a number of occasions because of his political opinion. As a matter of fact, such a person suffers to a lesser degree over a period of time, because after each detention he is release [sic] and enjoys his freedom. The wife on the other hand has no respite from her agony of torture and grief. She must endure these misfortunes continuously. The law should not sit idly by while those who seek relief lose hope, and those who abuse it are emboldened by its failure to provide sanctions. ${ }^{237}$

A recent decision that garnered widespread media attention involved the successful claim by a Somali woman and her two children. ${ }^{238}$ The daughter's claim was based on a well-founded fear of genital mutilation

236. Immigration and Refugee Board, "First Anniversary of Guidelines on Women Refugee Claimants" (News Release), 9 Mar. 1994. Statistics for refugee claims concluded in 1993 indicate that the overall acceptance rate for refugee claimants was 55 percent. Immigration and Refugee Board, Refugee Claims Statistics for 1993 Released (News Release), 28 Feb. 1994.

237. CRDD No. U92-08714, Maraj, Shecter, 4 June 1993, at 6-7. But see CRDD No. T9303535 Shymko, Qureshi, 30 July 1993 (claim by Jamaican woman denied on grounds that she had not taken advantage of avenues of redress available to her from the state).

238. CRDD T93-12197, 12198, 12199, Ramirez, MCCaffrey, 10 May 1994. 
should she be returned to Somalia. ${ }^{239}$ The panel ruled that "this minor claimant's right to personal security would be grossly infringed if she were forced to undergo female genital mutilation. . .."240 To its credit, the panel used African sources to document the practice, and noted that "[s]ubjecting a young girl to FGM is seen as a 'torturous custom' by women's rights advocates in Africa who are campaigning to eradicate this practice." 241

Another salient feature of this Somali decision is that the panel ruled that the daughter had a well-founded fear of persecution based on her membership in two particular social groups, namely women and minors. ${ }^{242}$ The panel explicitly referred to Ward in adopting a broad approach to designating the relevant social groups, ${ }^{243}$ while other decisions have followed a more restrictive approach and defined the particular social group in terms such as "Ecuadoran women subject to wife abuse"244 or "Bulgarian women vulnerable to wife abuse by men with government influence. ${ }^{245}$ The IRB has yet to adopt a preferred position with respect to defining a gendered social group category.

The Guidelines are still relatively new, and it is rumored that they may yet be revised in light of the Ward decision. For those interested in addressing the phenomenon of gender persecution in the refugee determination process elsewhere, the Guidelines are available as a template upon which one can devise a model tailored to the particular jurisdiction in which it will operate.

At a theoretical level, the Guidelines also present a challenge to implicit assumptions about the stability of categories. Finding a principled basis for admitting women who flee gender persecution requires a reevaluation of what refuge means. It also requires Western feminists to ask themselves searching questions about the shifting significance of the categories "woman" and "refugee" in local versus transnational contexts. What distinguishes the

239. A French tribunal accepted a similar claim in 1991: Re Aminate Diop, French Refugee Appeals Board, recours No. 164078 (Sept. 1991), reported in Case Abstract JJRL/0097, 4 INT'L J. REFUGEE L. 92 (1992). For a discussion of the case and its applicability in Canada under the new Guidelines, see Valerie Oosterveld, Refugee Status for Female Circumcision Fugitives: Building a Canadian Precedent, 51 U. Toronto FAC. L. Rev. 277 (1993). In the United States, a Federal Immigration Judge quashed a deportation order against a Nigerian woman who resisted the deportation because, inter alia, her daughters would probably be subjected to genital mutilation if they accompanied her. The judge did not grant her asylum, however. Clyde H. Farnsworth, Canada Gives Somali Mother Refugee Status, N.Y. Times, 21 July 1994, at A14.

240. CRDD T93-12197 et al., supra note 234, at 10 .

241. Id.

242. Id. at 11

243. Id. at 7 .

244. CRDD U92-08714, supra note 237.

245. CRDD T92-09592, Toth, Dualeh, 14 Sept. 1993. (positive). 
refugee claimant who flees Trinidad for Canada to escape an abusive husband from the Canadian citizen who flees Toronto for Swift Current for the same reason?

Like many other events in human experience, refugee determination is a process in which the subject's agency is subordinated to the definitional power of others. In exercising this power to confer the label "refugee" on a woman, we are forced to confront categorization as a political choice. Which women we call refugees, how and why we allocate them to that category, and which women we do not so designate, reveals as much about how we define ourselves as it does about those whom we define. 